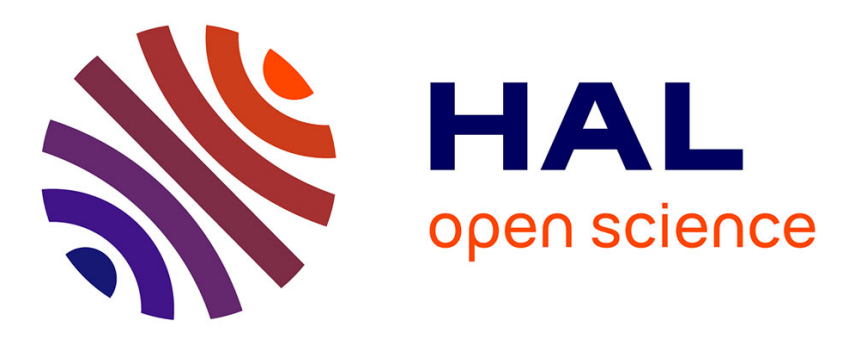

\title{
UPLC-MS/MS quantitative analysis and structural fragmentation study of five Parmotrema lichens from the Eastern Ghats
}

K Kumar, Bandi Siva, V U M Sarma, Satish Mohabe, a Madhusudana Reddy, Joël Boustie, Ashok K Tiwari, N Rama Rao, K Suresh Babu

\section{To cite this version:}

K Kumar, Bandi Siva, V U M Sarma, Satish Mohabe, a Madhusudana Reddy, et al.. UPLCMS/MS quantitative analysis and structural fragmentation study of five Parmotrema lichens from the Eastern Ghats. Journal of Pharmaceutical and Biomedical Analysis, 2018, 156, pp.45-57. 10.1016/j.jpba.2018.04.017 . hal-01807884

HAL Id: hal-01807884

https://hal-univ-rennes1.archives-ouvertes.fr/hal-01807884

Submitted on 3 Jul 2018

HAL is a multi-disciplinary open access archive for the deposit and dissemination of scientific research documents, whether they are published or not. The documents may come from teaching and research institutions in France or abroad, or from public or private research centers.
L'archive ouverte pluridisciplinaire HAL, est destinée au dépôt et à la diffusion de documents scientifiques de niveau recherche, publiés ou non, émanant des établissements d'enseignement et de recherche français ou étrangers, des laboratoires publics ou privés. 


\section{UPLC-MS/MS Quantitative analysis and structural fragmentation study of five Parmotrema lichens from the Eastern Ghats}

K. Kumar, ${ }^{\text {a\# }}$ Bandi Siva, ${ }^{\text {a\# }}$ V.U.M. Sarma, ${ }^{\text {a }}$ Satish Mohabe, ${ }^{b}$ A. Madhusudana Reddy, ${ }^{\text {b Joel }}$ Boustie, ${ }^{\mathrm{c}}$ Ashok K Tiwari, ${ }^{\mathrm{d}}$ N. Rama Rao, ${ }^{*}$ K. Suresh Babu. ${ }^{* a}$

${ }^{a}$ Natural Products Laboratory, Division of Natural Product Chemistry, CSIR-Indian Institute of Chemical Technology, Hyderabad 500 007, India

${ }^{\mathrm{b}}$ Department of Botany, Yogi Vemana University, Vemanapuram, Kadapa-516003

${ }^{c}$ Univ Rennes, CNRS, ISCR (Institut des Sciences Chimiques de Rennes)-UMR6226, F-35000

Rennes, France ${ }^{\mathrm{d}}$ Medicinal Chemistry and Biotechnology Division,CSIR-Indian Institute of Chemical Technology, Hyderabad 500 007, India

${ }^{\mathrm{e} C h a l a p a t h i ~ i n s t i t u t e ~ o f ~ P h a r m a c e u t i c a l ~ S c i e n c e s, ~ L a m, ~ G u n t u r-522034 ~}$

*To whom correspondence should be addressed. Tel: +91-40-27191881; Fax: +91-40-27160512; E-mail: suresh@iict.res.in (Dr. K. S. Babu)

\# Equal contribution

\section{Graphical Abstract}

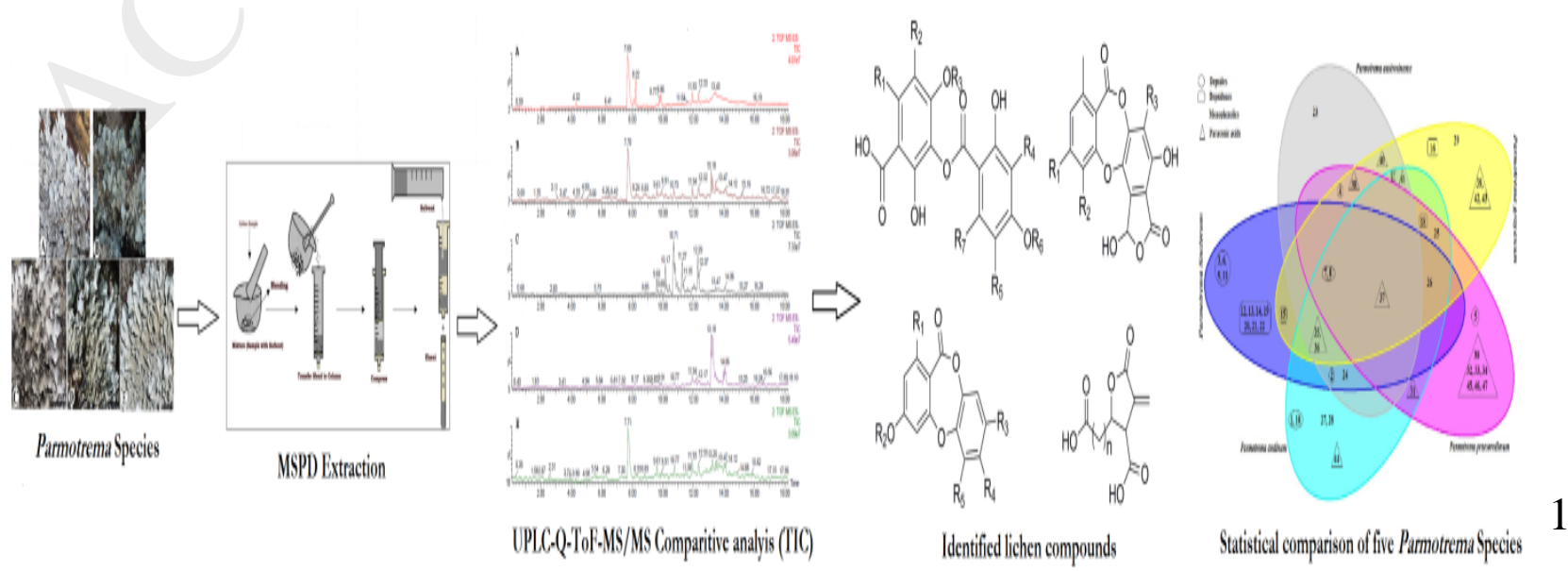




\title{
Highlights
}

- Design of a method to analyze lichen extracts through UPLC MS (HR MS/MS and MRM)

- Dozens of lichen compounds newly identified from five closely shaped Parmotrema species

- MS Fragmentation patterns analyzed for 5 classes of compounds

- Good anti-glycation activities for three lichen extracts collected in Eastern Ghats

\begin{abstract}
Comparative phytochemical analysis of five lichen species [Parmotrema tinctorum (Delise ex Nyl.) Hale, P. andinum (Mull. Arg.) Hale, P. praesorediosum (Nyl.) Hale, P. grayanum (Hue) Hale, P. austrosinense (Zahlbr.) Hale] of Parmotrema genus were performed using two complementary UPLC-MS systems. The first system consists of high resolution UPLC-QToFMS/MS spectrometer and the second system consisted of UPLC-MS/MS in Multiple Reaction Monitoring (MRM) mode for quantitative analysis of major constituents in the selected lichen species. The individual compounds (47 compounds) were identified using Q-ToF-MS/MS, via comparison of the exact molecular masses from their MS/MS spectra, the comparison of literature data and retention times to those of standard compounds which were isolated from crude extract of abundant lichen, $P$. tinctorum. The analysis also allowed us to identify unknown peaks/compounds, which were further characterized by their mass fragmentation studies. The quantitative MRM analysis was useful to have a better discrimination of species according to their chemical profile. Moreover, the determination of antioxidant activities $\left(\mathrm{ABTS}^{+}\right.$inhibition) and Advance Glycation Endproducts (AGEs) inhibition carried out for the crude extracts revealed a potential antiglycaemic activity to be confirmed for $P$. austrosinense.
\end{abstract}


Keywords: Parmotrema tinctorum, Parmotrema andinum, Parmotrema praesorediosum, Parmotrema grayanum, Parmotrema austrosinense, Parmeliaceae, Matrix solid-phase dispersion, UPLC-ToF-MS/MS, Metabolite profiling, Fragmentation studies

\section{Introduction}

Lichens are nutritionally specialized fungi living in symbiotic association between fungi and algae/cyanobacteria. Several lichen species have been used in traditional medicine for centuries and are gaining considerable interest as an alternative medicine for the treatment of various ailments in different parts of the world. Symbiosis in lichens leads to production of typical secondary metabolites that includes depsides, depsidones, dibenzofurans, anthraquinones, xanthones, pulvinic acid derivatives and napthoquinones $[1,2]$. These lichen substances are responsible bio-markers for a wide range of biological activities and ecological roles [3, 4].

In India, most of lichenological investigations are restricted either to Himalayan or the Western Ghats region. Nevertheless, recent studies indicate that the Deccan Plateau (DP) and the Eastern Ghats (EG) in southern part of India also present rich diversity of lichens. Around 180 lichen species are identified from this region of the country that has gained biological and economical importance [5, 6]. Several Parmotrema species are available in the EG region and most of them became part of folklore medicine in the tribal areas of Andhra Pradesh (AP), India [7]. Although the species are medicinally important, very few species have been verified scientifically with respect to their chemical constituents [8]. Right identification of lichen species 
is also a challenge and out of bar-coding studies, classifications of lichens are usually carried out by morphology, anatomy along with chemical data based on color reactions obtained on thallus and medulla and metabolite characterization based on thin layer chromatography (TLC) methods. However, most of these tests have some limits to distinguish minute differences between species [9]. Alternatively, study of lichen compounds by usual LC-MS techniques [10] or direct spectroscopic analysis [11-17] offers a helpful tool for chemotaxonomic determination of compounds and dereplication strategies $[18,19]$. Accurate techniques as UPLC-HRMS are now available to identify a number of compounds [20-23] but protocols are not still standardized. Although the number of compounds identified in such analysis is impressive, discrepancies between described compounds and expected compounds are in some cases disturbing. For instance, in the recent description of 37 metabolites found in a Colombian sample identified as Parmotrema robustum [21], it is questionable why protocetratic acid is not found while this depsidone and the depside atranorin are considered to be the major markers of this species [24]. Parmotrema species are also widely distributed in India and this genus comprises about 350 species from the Parmeliaceae family which is considered to be the largest family with 2,765 species all over the world [25-28]. Although P. robustum could not be found, five Parmotrema species where collected in a same location of the Eastern Ghats to be compared for their metabolite content. As part of our continuous studies on the exploration of natural flora for isolation of bioactive secondary metabolites $[29,30]$, we conducted a phytochemical study on $P$. tinctorum (Delise ex Nyl. Hale) which is abundant in the EG region of AP. Five compounds were isolated and fully characterized from its acetone extract and used as standards in subsequent profiling survey. Indeed, a liquid chromatography tandem mass spectrometry (UPLC-MS/MS) method was developed using two complementary UPLC-MS systems for identification, 
characterization and comparative metabolite profiling of Parmotrema species. The first system consisted of a high resolution UPLC-PDA-QToF-MS/MS spectrometer from which metabolites are identified through their MS fragmentation pattern and second system consisted of a UPLCMS/MS in Multiple Reaction Monitoring (MRM) mode for quantitative analysis of major constituents in the five Parmotrema species. Three extractive techniques were compared to optimize the lichen extract to be analyzed along with various mass spectrometric conditions. This study resulted in the characterization of about fifty compounds (47 secondary metabolites identified) along with ten unknown compounds (Fig. 1). All the metabolites were systematically identified through exact molecular masses from their MS/MS spectra, literature data and comparison of retention times with those of standard compounds, giving additional data to be valued in chemotaxonomy or natural compound discovery. Herein, we report quantitative and qualitative analysis along with a structural fragmentation study of metabolites of Parmotrema species along with free radical scavenging and advanced glycation end-products (AGEs) inhibitory capacities of extracts from five Parmotrema species.

\section{Materials and Methods}

\subsection{Lichen Samples}

Samples of Parmeliaceae family Parmotrema tinctorum, P. andinum, P. praesorediosum, P. grayanum and P. austrosinense species were collected from Horsely Hills of Eastern Ghats, Chittor district, Andhra Pradesh, India in the month of February 2015 with a referenced voucher specimen kept in the Yogi Vemana University Herbarium (SI, Table 1). Geographical location of horsely hills where lichens were collected at an altitude of $930-1150 \mathrm{~m}, 13^{\circ} 39.123^{\prime} \mathrm{N}$ and $78^{\circ}$ 34.117 $\mathrm{E}$, India. The morphological features of lichen thallus and ascomata were observed under magnüs MS 24/13, and spot test for color reaction were carried out standardized reagents given in (SI, Table1). For anatomical investigation of fruiting bodies light microscope of ZEISS 
Axiostar was used. The lichen substances were identified with thin layer chromatography in solvent system 'A' following White and James [31-33]. The standard literatures [34-36] were referred for identification of lichen samples.

\subsection{Chemicals and Reagents}

HPLC-grade acetonitrile was obtained from Biosolve Chimie SARL (Dieuze, France), formic acid (Optima LC/MS grade) from Fisher Scientific (Geel, Belgium,) and methanol (LiChrosolv) was purchased from Merck (Darmstadt, Germany). Ultra-pure water was used throughout study which was produced by Milli-Q water purification system (Millipore, Milford, MA, USA). Isolated pure compounds were used as standards for quantification.

\subsection{Experimental procedure for Isolation of major constituents from P. tinctorum}

Finely ground dry thalli of $P$. tinctorum $(50 \mathrm{~g})$ were extracted with acetone $(2 \mathrm{x} 1 \mathrm{~L})$ at room temperature for $48 \mathrm{~h}$. The extract was filtered through Whatman filter paper 41 and evaporated to dryness under reduced pressure to get a crude extract $(10 \mathrm{~g})$ which was subjected to silica gel column chromatography ( $\left.\mathrm{SiO}_{2}, 100-200 \mathrm{mesh}\right)$ with the elution of $\mathrm{n}$-hexane and ethyl acetate in the order of increasing polarity to yield six fractions (I-VI). Repeated purification of Fraction II using column chromatography $\left(\mathrm{SiO}_{2}, 100-200\right.$ mesh) eluted with hexane/acetone (80:20) gave 7 (atranorin). Hexane/acetone (60:40) gave compound 2 (lecanoric acid) Fraction III was purified by preparative TLC (silica gel) eluting with $\mathrm{CH}_{2} \mathrm{Cl}_{2} / \mathrm{AcOEt} / \mathrm{AcOH}$ (90:8:2) to afford compound 19 (norlobaridone) with $R_{f} 0.60$ and 24 (orsellinic acid) with $R_{f} 0.30$. Similarly, fraction IV and V were washed with acetone $(2 \mathrm{x} 10 \mathrm{ml})$ to get compound $\mathbf{2 6}$ (methyl $\beta$-orsellinate) respectively.

\subsection{Extraction procedures for preparation of lichen extracts for analysis}

In order to obtain the best extraction yields and the wider variety of lichen compounds from lichen thalli, we investigated various extraction procedures/conditions on $P$. tinctorum The 
considered parameters included the different (non-polar and polar) solvents for extraction [i.e. nhexane, diethyl ether, dichloromethane, tetrahydrofuran, ethyl acetate, acetone, acetonitrile, nbutanol, ethanol, methanol and Milli Q water with $5 \mathrm{mg} / \mathrm{mL}$, the extraction temperature (both hot and ambient conditions) and ultra-sonication (Fig. 2A). Each extraction condition was performed in triplicate and amount of extracted material was determined. Overall, it turned out that acetonitrile was a better extraction solvent than the other solvents. Based on this optimized solvent parameter, we moved to matrix solid phase dispersion (MSPD) extraction method for all lichens using acetonitrile as solvent (see supporting information for detailed extraction procedures).

The type of dispersant is a critical factor due to significant differences in adsorption capacity and selectivity of various dispersants [37]. In the present work, three types of dispersants $\left(\mathrm{SiO}_{2}, \mathrm{Al}_{2} \mathrm{O}_{3}\right.$, and $\left.\mathrm{RP} \mathrm{C}_{18}\right)$ were investigated. As shown in Fig. 2C, 1:2 ratio of sample to $\mathrm{C}_{18}$ dispersant is the most favorable proportion to extract lichen compounds with acetonitrile whatever the Parmotrema lichen thallus studied.

\subsection{Instrumental conditions}

\subsubsection{Chromatographic conditions}

Chromatographic separations were performed using a reverse phase hypersil gold column $(150 \times 2.1 \mathrm{~mm}, 1.9 \mu \mathrm{m})(\mathrm{USA})$ with the maintenance of ambient temperature $\left(25^{\circ} \mathrm{C}\right)$ throughout the experiment. Mobile phase was a mixture of millipore water (A), acetonitrile (B) and methanol (C) with $0.1 \%$ formic acid in all the solvents used as mobile phase at a flow rate of 0.4 $\mathrm{mL} / \mathrm{min}$. The elution consisted of a gradient program as follows: $\mathrm{t}(\mathrm{min}) / \% \mathrm{~B} / \% \mathrm{C}: 0 / 45 / 10$, $7 / 45 / 10,9 / 70 / 0,12 / 70 / 0,14 / 80 / 0,20 / 80 / 0$ and 22/45/10. The Injection volume was $2 \mu \mathrm{L}$ and wavelength range for UV scan was set at 200-400 nm. 


\subsubsection{Mass spectrometric conditions}

The chromatographic analysis was performed on a shimadzu nexera X2 UPLC system (Shimadzu Corporation, Nakagyo, Kyoto, Japan) equipped with a quaternary pump, an online degasser (DGU-20A 5R), a thermo stated auto sampler (SIL-30AC), a thermostatically controlled column compartment (CTO-20AC), and a diode array detector (PDA) (SPD-M20A), which were communicated through bus module (CBM-20A).

For LC-APCI-MS experiments, shimadzu triple quadruple mass spectrometer (LCMS 8040) (Shimadzu Corporation, Kyoto, Japan) equipped with an atmospheric chemical ionization (APCI) source was connected to UPLC instrument. The APCI source parameters were set as follows: ion spray voltage, $4.5 \mathrm{KV}$; Desolvation line temperature, $250^{\circ} \mathrm{C}$; APCI source temp at $350{ }^{\circ} \mathrm{C}$, Heat Block Temperature, $250{ }^{\circ} \mathrm{C}$; Nebulizing $\left(\mathrm{N}_{2}\right)$ and Dry gas $\left(\mathrm{N}_{2}\right)$ flow rates, 3.0 and 5.0 L/min, respectively. Argon gas was used as CID gas for MRM experiments. The mass analyzer was operated in positive and negative ion mode for MRM experiments with polarity switching at $15 \mathrm{msec}$, with a mass range of 50 to $500 \mathrm{~m} / \mathrm{z}$. Accurate masses were calibrated according to the manufacturer's guidelines using TQ Standard Sample (PEG, PPG and Raffinose) (Shimadzu corporation, Kyoto, Japan). Data were recorded and processed using the LCMS Lab Solutions 5.60 SP2 software (Shimadzu Corporation, Kyoto, Japan).

High-resolution masses of metabolites were measured after UPLC separation. Chromatographic separation was performed on acquity H Class UPLC system (Waters, Milford, MA, USA) with a conditioned auto sampler, using an Acquity BEH $\mathrm{C}_{18}$ column (100 mm X 2.1mm i.d., $1.7 \mu \mathrm{m}$ particle size) (Waters, Milford, MA, USA). The column temperature was maintained at $25{ }^{\circ} \mathrm{C}$. The mobile phase consisting of water with $0.1 \%$ formic acid in water (solvent A) and acetonitrile (solvent B) was pumped at a flow rate of $0.4 \mathrm{~mL} / \mathrm{min}$. The gradient 
elution program was as follows: $0 \mathrm{~min}, 5 \% \mathrm{~B} ; 3.00 \mathrm{~min}, 20 \% \mathrm{~B} ; 5.00 \mathrm{~min}, 35 \% \mathrm{~B} ; 7.50 \mathrm{~min}$, $50 \% \mathrm{~B} ; 10.00 \mathrm{~min}, 70 \% \mathrm{~B} ; 11.50 \min , 85 \% \mathrm{~B} ; 12.50 \min 95 \% \mathrm{~B} ; 17.00 \min 95 \% \mathrm{~B} ; 18.00 \min$ $5 \%$ B. Equilibration time was 5 min and the injection volume was $1 \mu \mathrm{L}$. LC-MS ${ }^{\mathrm{e}}$ mode was applied to analyze the samples in both TIC as well as MS/MS mode where collision energy was ramped at $5 \mathrm{eV}-40 \mathrm{eV}$. Eluted compounds were detected from m/z 50 to m/z 1200 using Xevo G2-XS QTOF mass spectrometer (Waters, Manchester, UK), which was connected to Electrospray ionization (ESI) interface with negative ion mode using the following instrument settings, capillary voltage, $2.0 \mathrm{KV}$; sample cone, $30 \mathrm{~V}$; source temperature, $120{ }^{\circ} \mathrm{C}$; desolvation temperature $350{ }^{\circ} \mathrm{C}$; cone gas flow rate $50 \mathrm{~L} / \mathrm{Hr}$; desolvation gas $\left(\mathrm{N}_{2}\right)$ flow rate $1000 \mathrm{~L} / \mathrm{Hr}$, Argon as CID gas for MS/MS experiments. All analyses were performed using the lock spray, which ensured accuracy and reproducibility. Leucine - Enkephalin $(5 \mathrm{ng} / \mathrm{mL})$ was used as lock mass generating a reference ion in negative mode at $\mathrm{m} / \mathrm{z} 554.2615$ and introduced by a lock spray at $10 \mu \mathrm{L} / \mathrm{min}$ for accurate mass acquisition. Data acquisition was achieved using MassLynx $v$ 4.1. Acquiring data in this manner provided the collection of information of intact precursor ions as well as fragment ions.

\subsection{Biological Activity}

\subsubsection{ABTS ${ }^{++}$free-radical scavenging assay}

[2, 2'-azinobis-(3-ethylbenzothiazolin-6-sulphonic acid] radical cation $\left(\mathrm{ABTS}^{+}\right)$ scavenging activity was performed as reported [38]. Decolorization of $\mathrm{ABTS}^{+}$was measured as free-radical scavenging antioxidant capacity of crude extracts. Absorbance of $\mathrm{ABTS}^{+}$ decolorization was measured at $734 \mathrm{~nm}$ spectrophotometrically (BioTek synergy 4 multi-mode microplate reader, Bio Tek Instruments, Inc Winooski, VT, USA). Serial dilutions of extracts 
were prepared and studied to find radical scavenging 50\% concentrations. Trolox was taken as standard reference compound.

\subsubsection{Advanced glycation end products (AGEs) inhibitory assay}

Glycation of bovine serum albumin protein was induced in hyperglycemic environment seven days [39]. Aminoguanidine was choice of reference AGEs inhibitor. The vesperlysine-like $\left(\Lambda_{\mathrm{exc}} 370 \mathrm{~nm} ; \Lambda_{\mathrm{em}} 440 \mathrm{~nm}\right)$ and pentosidine-like $\left(\Lambda_{\mathrm{exc}} 335 \mathrm{~nm} ; \Lambda_{\mathrm{em}} 385 \mathrm{~nm}\right)$ AGEs inhibitory capacity of lichen extracts were analyzed [40].

\section{Results and Discussion}

\subsection{Collection and identification of samples}

In the present study, five species of Parmotrema having a closely shaped grey thallus $[P$. tinctorum (Delise ex Nyl.) Hale (PT), P. andinum (Mull. Arg.) Hale (PA), P. praesorediosum (Nyl.) Hale (PP), P. grayanum (Hue) Hale (PG), P. austrosinense (Zahlbr.) Hale (PS)] were collected on rocks from Horsely Hills of Eastern Ghats at ca. 1000m altitude (SI, collection site and Table 1S). As usual, they were identified by morphological characters and thallus reactions which clearly distinguished PG and PP (negative reaction of the medulla to calcium hypochlorite solution (C-)) from the three other species (PA, PS and PT with a C+ red medulla) (Table 1S). However, thallus reactions can be variable and give poor indications for the identification of secondary metabolites of the studied Parmotrema lichens. HPTLC (Fig. 1S) and UPLC-PDA profiles (Fig. 2S) were more informative for chemical constituents as atranorin (7) and chloratranorin $(\mathbf{8})$ were visualized in all the species while abundant yields of lecanoric acid (22) and orsellinic acid (24) appear to be present in PT, PS and PA only, confirming the two subgroups. Lens-magnified and microscope observed anatomical characters were considered to discriminate the five species (Fig. 2S) but a more accurate information was expected from a 
qualitative and quantitative mass analysis for secondary metabolites analysis from optimized lichen extracts.

\subsection{Isolation of compounds from P. tinctorum (Despr.ex Nyl) Hale}

Parmotrema tinctorum was abundantly available from seashore rocks or bark trees in EG, we first carried a phytochemical study on this lichen which also appears to be a good source for standards. $50 \mathrm{~g}$ of $P$. tinctorum were extracted in acetone and further subjected to repeated column chromatography and preparative TLC to result in the isolation of five known compounds $(\mathbf{2}, \mathbf{7}, \mathbf{1 9}, \mathbf{2 4}, \mathbf{2 6})$. Structures of these compounds were identified as monoaromatic phenols orsellinic acid (24) and methyl $\beta$-orsellinate (26), depsides lecanoric acid (2) and atranorin (7), and the depsidone norlobaridone (19) from the analysis of their spectroscopic data (Figure 8S12S) and comparison with literature data [1].

3.3. Identification and comparative analysis of secondary metabolites from Parmotrema species

\subsubsection{UPLC-ToF-MS/MS analysis}

UPLC-MS is a powerful tool for the qualitative and quantitative analysis of secondary metabolites from lichens [41]. Recently Carlos Areche' team described lists of compounds in two Parmotrema and four Usnea species from South-America [22, 42]. Lichen secondary metabolite structures frequently have carboxyl or phenyl groups and thus could be readily ionized via electrospray ionization (ESI) source. Initially, chemical constituents of $P$. tinctorum were analyzed by reversed-phase UPLC-MS eluted with gradient mobile phase consisting of acetonitrile and water containing $0.1 \%$ formic acid. This allowed elution of all analytes within 18 minutes. Based on these optimized conditions, acquired UPLC-PDA and MS total ion chromatograms (TIC) of five Parmotrema species were analyzed in ESI negative ionization mode and these results are presented (Fig. 3). To confirm results and structures of metabolites, 
ESI-Q ToF-MS/MS analysis was performed. The peak results were identified based on their MS spectral data (accurate mass and fragmentation pattern), retention times, comparison to the standard compounds, and searching in public online-databases (DNP, Reaxys, SciFinder). Presence of a particular type of metabolite has been proposed based on the occurrence of characteristic molecular ion peak and further analysis of its fragmentation ions implied the structure of metabolite $[14,41]$. In the present study a total of 47 compounds were clearly characterized from the five lichen species by molecular formula generated by ToF-MS/MS and Relative Double Bond Equivalence (RDBE) including their biogenetic pathway as reported in the literature [42, 43]. Among them, 47 secondary metabolites were tentatively identified and characterized by their diagnostic fragment ion peaks in the MS/MS spectrum in Table 1.

The representative LC-MS base-peak chromatograms of Parmotrema species are presented (Fig. 3). As shown, five compounds (orsellinic acid (24), lecanoric acid (2), methyl $\beta$-orsellinate (26), norlobaridone (19), and atranorin (7)) were found at $4.34 \mathrm{~min}, 7.71 \mathrm{~min}, 7.87 \mathrm{~min}, 10.62 \mathrm{~min}$, and $11.94 \mathrm{~min}$ in LC-PDA chromatograms (Fig. 3S) at $254 \mathrm{~nm}$ for P. tinctorum and these compounds were confirmed with the comparison of pure authentic compounds. By taking these compounds as representative standards, we further also compared and analyzed the distribution of these major metabolites among the remaining four species. LC-QToF-MS/MS analysis (TIC) of the optimized lichen extracts confirmed the presence of the main common compounds already described in these Parmotrema species but also a series of 10 additional lichen metabolites not previously described in any of the studied species. Structures are tentatively assigned to lichen secondary metabolites from which some remain to be specified as ambiguous isomers (e.g. dihydrolichesterinic acid which can corresponds to roccellaric acid or nephromopsic acid), non described compounds (e.g. orsellinylgyrophorate, dehydronephrosterinic acid, 
norprotopraesorediosic acid) and ten unknown compounds. We generated a venn diagram (Fig. 7S) which clearly shows distribution and classification of known compounds in the five Parmotrema species. While atranorin (7) and chloratranorin (8) are produced by all these species, some compounds are only found in a given species (e. g. papulosic derivatives in $P$. andinum). A real chemotaxonomic value cannot be ascertained without a statistical analysis of multiple specimens but the Venn diagram (Fig. 7S) suggests a clear distinction between $P$. praesorediosum which produces a variety of paraconic acids and $P$. tinctorum containing depsides and depsidones predominantly. The chemical profile of these species is more complete and in accordance with the presence of the major compounds described by lichenologists [24, 44]. Additional compounds have been isolated or characterized in recent studies for $P$. praesorediosum [36, 45, 46], $P$. grayanum [23, 41], and $P$. andinum [21]. In addition to compounds found in such analysis, diphenylethers and phtalides have been isolated and identified from $P$. praesorediosum by a Vietnamese team from large quantities of a lichen sample collected in Thailand [36]. A mixture of collected species cannot be excluded as the unexpected usnic acid and isousnic acids are described. Moreover, extensive use of $\mathrm{MeOH}$ in the process could have generated artefacts [47] as methyldivaricatic acid but these differences also suggest the analytical techniques cannot be considered as fully exhaustive, whatever accurate and informative they are. Considering $P$. grayanum from which compounds have been isolated and identified from samples collected in Sri Lanka, it is highly questionable to find lecanoric acid and usnic acid mentioned in a first publication [23]. Usnic acid is not described again in recent LC MS/MS QTOF analysis of this species collected in Sri-Lanka [22, 41]. Additionally, the chemical profile with the depsides lecanoric acid, divaricatic acid sekikaic acid and absence of paraconic acids is not fitting the described $P$. grayanum typus profile $[24,48]$. This suggests a 
misidentification of the collected samples to be checked again from the deposited voucher samples. One of the studied species, $P$. andinum was also analysed by UPLC HR-ESI MS/MS collected from northern Peru [21] reporting the presence of 30 metabolites versus 18 in our analysis. However only five compounds were found as the same in the two experiments including the two depsides lecanoric acid and atranorin recognized as markers of this species [49] . Differences in protocols used to prepare the extracts to be analysed can explain part of these discrepancies. Parallel analysis of a variety of specimens in a standardized protocol and a barcoding analysis of the studied samples would be the best approach to be conclusive. Facing this situation, we consider a sharp chemotaxonomic discussion is beyond the frame of this study, most of all carried out to investigate the contribution of hyphenated accurate mass spectrometry techniques to lichen chemical profiling.

\subsubsection{Mass fragmentation study}

In the present work, identification of minor compounds in each species was analyzed by UPLC-QToF-MS/MS in the ESI negative mode using a high-resolution detection. Accordingly, each species was subjected to UPLC-QTOF-MS/MS in ESI mode (negative) in order to determine molecular formula of detected depsides, depsidones, paraconic acids and monophenolic compounds. Consideration of their UV absorption in PDA, triple quadruple mass and high resolution masses allowed dereplication of the known compounds as well as preliminary characterization of new metabolites in all the species. Results are shown in Table 1. All the metabolites were classified based on their common fragmentation ion in MS/MS spectra. Depside class of compounds possesses common fragmentation through the breakage of ester bond between two phenolic rings as shown [41, 50, 51] (Fig. 4). Similarly, in depsidones fragmentation ions appear through the simple loss of $\mathrm{CO}_{2}, \mathrm{H}_{2} \mathrm{O}, \mathrm{CH}_{2} \mathrm{O}$, followed by cyclization, 
while loss of $\mathrm{CO}_{2}$ and alkane chain breakage were seen in paraconic acids. Initially, known compounds atranorin (7), orsellinic acid (24), norlobaridone (19) and salazinic acid (14) were taken as representative compounds for each group and their ToF-MS/MS spectra were analyzed (Fig. 4S). Then efforts were made to analyze secondary metabolites of each class through their fragmentation patterns.

\subsubsection{Structural analysis and fragmentation pattern of Depsides (1-11)}

Compounds 1-10 belong to depside class of metabolites and $[\mathrm{M}-\mathrm{H}]^{-}$ions for these were detected in ESI-QToF-MS (negative mode) scan. The CID-MS profiles were almost similar to those of standard depsides as shown (Fig. 5S\&4), which clearly indicate similar skeletons including position of substituted groups of these compounds (2, 7 and 1-8). Compound $\mathbf{1}$ is used as a representative compound for the following discussion and structure analysis of depsides. The molecular formula of $\mathbf{1}$ was confirmed as $\mathrm{C}_{16} \mathrm{H}_{13} \mathrm{O}_{8}[\mathrm{M}-\mathrm{H}]^{-}$from the accurate mass, relative isotopic abundance (RIA) measurements and the MS/MS spectrum. The high abundance product ion at $\mathrm{m} / \mathrm{z}$ 183.0297, 167.0342 were formed from pseudo-molecular ion $[\mathrm{M}-\mathrm{H}]^{-}$at $\mathrm{m} / 2333.0611$ by cleavage of ester bond (Fig. 4). Further fragmentation of these ions afforded product ions due to sequential losses of $\mathrm{CO}_{2}$ and $\mathrm{H}_{2} \mathrm{O}$, respectively. Similarly, ESI-MS/MS spectrum showed $[\mathrm{M}-\mathrm{H}]^{-}$ions of more substituted phenols such as compound $\mathbf{1 0}$ which showed molecular formula $\mathrm{C}_{16} \mathrm{H}_{11} \mathrm{O}_{9}[\mathrm{M}-\mathrm{H}]^{-}$, indicating 14 Da more than papulosic acid (1) in Table 1 and an additional DBE. The ToF-MS/MS analysis of compound 10 showed fragment ions at $\mathrm{m} / \mathrm{z}$ $197.0083,153.0190$ by cleavage of the ester bond followed by loss of CO indicating presence of aldehyde group positioned adjacent to the acid group. Based on this fragmentation pathway, structure of $\mathbf{1 0}$ was proposed as an oxidized papulosic acid derivative, which is tentatively identified as a new compound (Table 1). By following similar fragmentation pathways, we 
concluded the structures of remaining depsides (1-9) and detailed fragmentation patterns are shown in supporting information.

\subsubsection{Structural analysis and fragmentation pattern of Depsidones (12-22)}

The $[\mathrm{M}-\mathrm{H}]^{-}$ions for compounds 12-22 were detected in negative ion mode and the fragmentation profiles are similar to the standard depsidone type of compound, salazinic acid (14) indicating similar skeletons with substitutions. Salazinic acid (14) is used as a representative compound for the following discussion and structure analysis. A high abundance product ion at $m / z 343.0455$ was formed from the precursor $[\mathrm{M}-\mathrm{H}]^{-}$ions by sequential loss of $\mathrm{CO}_{2}$ in $\mathrm{MS} / \mathrm{MS}$ spectrum, as seen from fragmentation patterns for the depsidones [19]. Further, fragmentation afforded product ions at $\mathrm{m} / \mathrm{z} 313.0346$ by loss of $\mathrm{CH}_{2} \mathrm{O}$, at $\mathrm{m} / \mathrm{z}, 269.0451$ by loss of $\mathrm{CO}_{2}$. The molecular weight of $\mathbf{1 2}$ differs from salazinic acid (14) with 2Da and fragmentation pattern of 12 was indicating the product ions at $\mathrm{m} / \mathrm{z}$ 371.0401, 345.0607, 327.0505, 309.0401, 297.0401by sequential loss of $\mathrm{CO}_{2}, \mathrm{H}_{2} \mathrm{O}$ and $\mathrm{CH}_{2} \mathrm{O}$ etc. Furthermore, lack of one DBE in $\mathbf{1 2}$ when compared to salazinic acid, was indicating the presence of $-\mathrm{CH}_{2} \mathrm{OH}$ group in $\mathbf{1 2}$ instead of $-\mathrm{CHO}$ as in salazinic acid. Thus, structure of compound $\mathbf{1 2}$ was assigned as a consalazinic acid. Based on above strategy and fragmentation pathways (Fig. 5), structures of remaining depsidones were assigned and detailed fragmentation studies are shown in supporting information.

\subsubsection{Structural analysis and fragmentation pattern of mono-phenolic compounds (23-29)}

It is well known fact that biosynthetically lichen substances were formed from simple phenolic compounds $[14,51]$. The orsellinic acid (24) was taken as a standard for structural analysis of mono-phenolic compounds (23-29). Analysis of MS data obtained for 26 and 27 indicated similarities with orsellinic acid (24) and its fragmentation ions. From MS data, it is also observed that molecular weight of $\mathbf{2 6}$ was more than orsellinic acid (24) by 14Da with an 
additional DBE. Further analysis of its product ion at $\mathrm{m} / z 123.0446[\mathrm{M}-\mathrm{H}]^{-}$indicated the sequential loss of $\mathrm{CO}_{2}, \mathrm{CO}$ which provided information about presence of aldehyde group instead of methyl group. Similarly, presence of the product ion at $\mathrm{m} / z 79.0556$ in MS/MS spectrum of 27 indicated the presence of $-\mathrm{CH}_{2} \mathrm{OH}$ group instead of methyl group as in orsellinic acid (24). Based on these fragmentation pathway parameters (Fig. 6), the structures of remaining mono-phenolic compounds were analyzed and compounds (27-28) were found to be tentatively new compounds for which the fragmentations were proposed for the first time.

\subsubsection{Structural analysis and fragmentation pattern of paraconic acids (30-47)}

As analyzed, compounds 30-47 belong to the class of paraconic acid/aliphatic acid-type compounds. The fragmentation pathways and profiles of product ions for 30-47 were same in each case. To determine their structures, we compared the fragmentation pathways and profile of product ions with reference, DBE and UV absorbance. It was found that the fragmentation pathways of major product ions are very similar but crossing data was informative. As for compounds 30, 31 and $\mathbf{3 4}$ compounds with same molecular formula had proposed structures based on fragment ions, $\mathrm{R}_{\mathrm{f}}$ values and literature. Protolichesterinic acid (36) taken as an example [52], ToF-MS/MS spectrum indicated the product ions at $\mathrm{m} / \mathrm{z} 279.2325,235.2428$ formed from the molecular ions by sequential $\mathrm{CO}_{2}$ losses and aliphatic chain breakage. Losses of acetyl group and side chains in some of the compounds are also observed. Based on this fragmentation pathway (Fig. 7), molecular formula and HR-MS/MS fragments (Table 1), structures of 39-40 and 42-47 were proposed in Fig. 1. Fragmentation patterns for these compounds were shown in supporting information.

\subsubsection{Structural analysis of other compounds 48 to 57}


From these four Parmotrema species, ten additional compounds were characterized from elemental constituents and fragmentation pathways, including an additional chlorinated compound in PP (Table 1). Skeleton could not be identified because of a lack of reference compounds but the potential for discovering new chemical entities in lichens is once again illustrated

\subsection{Quantitative analysis of six major compounds in Parmotrema species}

Quantitative analysis of five compounds (orsellinic acid, lecanoric acid, methyl $\beta$ orsellinate, norlobaridone and atranorin) (Fig. 1) were performed using UPLC-APCI-MS/MS in multi reaction monitoring (MRM) mode of detection (Fig. 5S). The derived calibration curves of five compounds were characterized by adequate linearity $\left(\mathrm{R}^{2} \geq 0.998\right)$ and LODs were defined in the range $0.05-0.005 \mu \mathrm{g} / \mathrm{mL}$, while LOQs ranged from 0.20 to $0.02 \mu \mathrm{g} / \mathrm{mL}$ as given in Table $2 \mathrm{~S}$. Method was also precise, even for trace analysis of compounds. The relative standard deviation (\% RSD) value of retention times (Rt) for the precision (intra-day and inter-day variability) were less than $5 \%$ in Table $1 \mathrm{~S}$ while \% RSD $(\mathrm{n}=3)$ of peak areas ranged from 0.952 to 4.338 in Table 1S. The mean recovery of each compound revealed desirable figures between $96.09 \pm 1.14 \%$ to $103.69 \pm 1.15 \%$ in Table $2 \mathrm{~S}$. The results of the quantitative analysis were shown in Table 2, which clearly indicated that atranorin (7) and methyl $\beta$-orsellinate (26) were present in all Parmotrema species while orsellinic acid (24) is found in two species (PT and PA) and norlobaridone (19) in PT only. Lecanoric acid (2) is found as the major compound in three species of Parmotrema (PT, PA, PS), among them PT contains high quantity (\# $0.71 \mathrm{~mol} / \mathrm{mg}$ ). Although yields can be significantly modified in a given species by environmental factors [53] the contrasted ratio between common compounds could be considered as a chemotaxonomic marker. PS and PT being collected in a close location and at the same period, atranorin (7) and 
lecanoric acid (2) are the two major depsides for PT while only lecanoric acid should be considered for PS. It is also worth mentioning that norlobaridone (19) is only found in PT (\# 0.02 $\mathrm{mol} / \mathrm{mg}$ ) in trace amount and can therefore explain the absence of description in PT from usual TLC used.

\subsection{Biological activity}

Lichens are a rich resource of novel bioactive compounds and their antioxidant potential is well documented [54]. Their antidiabetic potential has received considerable attention in the recent past. The Parmotrema species, including P. tinctorum [55] has shown promising potential in both antidiabetic and antioxidant [56]. Therefore, investigation of lichens as an alternative antidiabetic food source presents an exciting opportunity.

\subsubsection{Free radical scavenging antioxidant activity}

All the crude acetonitrile extracts of Parmotrema species were evaluated for their ABTS ${ }^{+}$ radical scavenging antioxidant activity. Results are presented in Table 3. Decolorization assay of $\mathrm{ABTS}^{+}$is most popular and simple assay applicable for evaluating antioxidant activity of natural food materials [57]. Among five lichen extracts, PP extract followed by that of PT happened to be the most potent extracts bearing antioxidant activity. These activities might be arising due the presence of huge number of polyphenolic and acid compounds in these lichens [58]. In PS extract however, we could not detect ABTS $^{++}$scavenging activity.

\subsubsection{Advance glycation end products (AGEs) inhibition}

Oxidative stress in hyperglycemic individuals is identified as crucial step in initiating development of diabetic complication [59]. Formation of increased AGEs in hyperglycemic condition promotes development of oxidative stress [60]. Therefore, inhibition of AGEs formation is an important step in controlling development of diabetic complications [38]. 
Extracts of PA and PS were equipotent in inhibiting pentosidine-like AGEs as aminoguanidine. However, only PT and PS extracts could inhibit vesperlysine-like AGEs (Table 3). The pentosidine-like AGEs are identified in plasma, erythrocytes [61] and in bone of diabetic people [62] whereas vesperlysine-like AGEs are recorded in lens of diabetic individuals [61]. The $P$. austrosinense extract has a good activity on these too targets with no antioxidant activity in the ABTS assay, which is suggesting a possible specific mechanism of action. So this lichen species will be investigated in order to better assess its potential against development of diabetic complications.

\section{Conclusions}

Overall, the comparative metabolite profiling of five lichen species of Parmotrema were performed using two complementary UPLC-MS systems. After optimization of parameters, the UPLC-QToF-MS/MS method led to identify a total number of about 47 compounds including nine new compounds. Further, minor compounds were identified through their exact molecular masses from their MS/MS spectra, the comparison of literature data and fragmentation pathways were proposed for each compound. On the other hand, we also developed UPLC-APCI-MS/MS in MRM for the quantification of five common lichen substances (orsellinic acid, lecanoric acid, methyl $\beta$-orsellinate, norlobaridone, and atranorin) in five lichen species. Both UPLC-PDAQToF-MS/MS and UPLC-APCI-MRM methods helped in identification of several compounds in all species including standards, which were useful for the dereplication to decrease the tedious process of isolation. As suitable for minute amount of raw material and more informative than the thallus reactions and TLC profiles usually performed in lichen identification, these methods are of great interest for lichen analysis. However as illustrated by major discrepancies in metabolite profiles according to authors, a reliable bank data has to be built using a standardized 
and validated protocol. Identification of lichen species should be based on barcoding and anatomic approaches also taking into account environmental conditions. These experiments also suggest the importance of lichen genus Parmotrema in Eastern Ghats area as a reservoir of new secondary metabolites and stimulate us to focus some phytochemical studies on species having a number of unknown compounds. In addition to the interest to constitute a library of lichen compounds having a large panel of bioactivities, the presence of AGEs inhibitory activities in these lichen species is also incentive, particularly for the species $P$. austrosinense.

\section{Acknowledgements}

Didier Masson is highly acknowledged for his insightful comments and expertise on Parmeliaceae lichens. This research was performed as a part of the Indo-French LIA 'Natural Products and Synthesis for Affordable Health' and acknowledgments are due to CSIR (India) and CNRS (France). Authors thank to Director, IICT for his constant encouragement and support. BS thanks to CSIR for fellowship program and financial support. 


\section{References}

[1] S. Huneck, I. Yoshimura, Identification of Lichen substances, Springer (1996) Berlin, Heidelberg.

[2] J. A. Elix, A Catalogue of Standardized Chromatographic Data and Biosynthetic Relationships for Lichen Substances (2014) Third Edition, Canberra.

[3] K. Molnára, E. Farkasb E, Current Results on Biological Activities of Lichen Secondary Metabolites: a Review, Z Naturforsch C. 65 (2010) 157 - 173.

[4] P. Z. Vasudeo, P. C. Lew, Biopharmaceutical potential of lichens. Pharm Biol. 50 (2012) $778-798$.

[5] A. M. Reddy, S. Nayaka, P. C. Shankar, S. R. Reddy, B. R. P. Rao, New distributional records and checklist of lichens for Andhra Pradesh, India. The Indian Forester. 137 (2011) $1371-1376$.

[6] S. Nayaka, A. M. Reddy, P. Ponmurugan, B. A. Devi, G. Ayyappadasan, D. K. Upreti, Eastern Ghats, biodiversity reserves with unexplored lichen wealth, Curr Sci. 104 (2013) $821-825$.

[7] D. B. Anjali, S. Mohabe, A. M. Reddy, S. Nayaka, Antimicrobial activities of 2-Propanol crude extract from lichen Parmotrema tinctorum (Despr.ex. Nyl.) Hale, collected from Eastern Ghats, India. Curr Res Environ Appl Mycol. 5 (2015) 160 - 168.

[8] A. Ganesan, M. Thangapandian, P. Ponnusamy, J. P. Sundararaj, S. Nayaka, Antioxidant and antibacterial activity of parmeliod lichens from Shevoroy hills of Eastern Ghats, India. Int J PharmTech Res. 8 (2015) 13 - 23.

[9] N. K. Honda, W. Vilegas, A Química Dos Liquens, Quim Nova. 21 (1998) 110 - 125. 
[10] V. Shukla, D. K. Patel, R. Bajpai, M. Semwal, D. K. Upreti, Ecological implication of variation in the secondary metabolites in Parmelioid lichens with respect to altitude, Environ Sci Pollut Res Int. 23 (2016) 1391 - 1397.

[11] G. B. Alcantara, N. K. Honda, M. M. Castro Ferreira, A. G. Ferreira, Chemometric analysis applied in ${ }^{1} \mathrm{H}$ HR-MAS NMR and FT-IR data for chemotaxonomic distinction of intact lichen samples, Anal Chim Acta. 595 (2007) 3 - 8.

[12] S. K. Oettl, J. Hubert, J. M. Nuzillard, H. Stuppner, J. H. Renault, J. M. Rollinger, Dereplication of depsides from the lichen Pseudevernia furfuracea by centrifugal partition chromatography combined to ${ }^{13} \mathrm{C}$ nuclear magnetic resonance pattern recognition, Anal Chim Acta. 846 (2014) 60 - 67.

[13] M. Le Corvec, C. Boussard-Plédel, F. Charpentier, N. Fatih, B. Le Dare, F. Massart, F. Rojas, H. Tariel, O. Loreal, B. Bureau, J. Boustie, O. Sire, F. LohezicLe Devehat, Chemotaxonomic discrimination of lichen species using an infrared chalcogenide fibre optic sensor: a useful tool for on-field biosourcing, RSC Adv. 6 (2016) 108187 - 108195.

[14] P. Le Pogam, A. Schinkovitz, B. Legouin, A. C. Le Lamer, J. Boustie, P. Richomme, Matrix-Free UV-Laser Desorption Ionization Mass Spectrometry as a Versatile Approach for Accelerating Dereplication Studies on Lichens, Anal Chem. 87 (2015) 10421 - 10428.

[15] V. K. Mittermeier, N. Schmitt, L. P. Volk, J. P. Suárez, A. Beck, W. Eisenreich, Metabolic Profiling of Alpine and Ecuadorian Lichens, Molecules. 20 (2015) 18047 $-18065$. 
[16] P. Le Pogam, A. C. Le Lamer, B. Legouin, J. Boustie, D. Rondeau, In situ DART-MS as a Versatile and Rapid Dereplication Tool in Lichenology: Chemical Fingerprinting of Ophioparma ventosa, Phytochem Anal. 27 (2016) 354 - 363.

[17] H. Kai, K. Kinoshita, H. Harada, Y. Uesawa, A. Maeda, R. Suzuki, Y. Okada, K. Takahashi, K. Matsuno, Establishment of a Direct-Injection Electron Ionization-Mass Spectrometry Metabolomics Method and Its Application to Lichen Profiling, Anal Chem. 89 (2017) 6408 - 6414.

[18] R. D. Hiserodt, D. F. Swijter, C. J. Mussinan, Identification of atranorin and related potential allergens in oak moss absolute by high-performance liquid chromatographytandem mass spectrometry using negative ion atmospheric pressure chemical ionization, $\mathrm{J}$ Chromatogr A. 888 (2000) 103 - 111.

[19] D. Parrot, S. Jan, N. Baert, S. Guyot, S. Tomasi S, Comparative metabolite profiling and chemical study of Ramalina siliquosa complex using LC-ESI-MS/MS approach, Phytochemistry. 89 (2013) 114 - 124.

[20] F. Salgado, L. Albornoz, C. Cortez, E. Stashenko, K. Urrea-Vallejo, E. Nagles, C. Galicia-Virviescas, A. Cornejo, A. Ardiles, M. Simirgiotis, O. Garcia-Beltran, C. Areche, Secondary Metabolite Profiling of Species of the Genus Usnea by UHPLC-ESI-OT-MSMS, Molecules. 23 (2018) 54 - 69.

[21] A. Torres-Benitez, M. Rivera-Montalvo, B. Sepulveda, O. N. Castro, E. Nagles, M. J. Simirgiotis, O. Garcia-Beltran, C. Areche, Metabolomic Analysis of Two Parmotrema Lichens: P.robustum (Degel.) Hale and P.andinum (Mull. Arg.) Hale Using UHPLC-ESI-OT-MS-MS, Molecules. 20 (2017) 1861-1872. 
[22] S. G. Musharraf, F. Siddiqi, A. Ali, V. M. Thadhani, Sensitive analysis of bioactive secondary metabolites in lichen species using liquid chromatography-mass spectrometry, J Pharm Biomed Anal. 146 (2017) 279-284.

[23] V. M. Thadhani, M. I. Choudhary, S. Ali, I. Omar, H. Siddique, V. Karunaratne, Antioxidant activity of some lichen metabolites, Nat Prod Res. 25 (2011) 1827-1837.

[24] C. W. Smith, A. Aptroot, Brian J. Coppins, A. Fletcher, O.L. Gilbert, P.W. James, P. A. Wolseley, The Lichens of Great Britain and Ireland, British Lichen Society, 2nd edition (2009), Natural history Museum Publications, London

[25] O. Blanco, A. Crespol, P. K. Divakar, J. A. Elix, H. T. Lumbsch, Molecular phylogeny of parmotremoid lichens (Ascomycota, Parmeliaceae), Mycologia. 97 (2005) 150-159.

[26] A. Crespo, F. Kauff, P. K. Divakar, R. Del Prado, S. P. Ortega, G. Amo de Paz, Z. Ferencova, O. Blanco, B. R. Valiente, J. N. Zapata, P. Cubas, A. Arguello, J. A. Elix, T. L. Esslinger, D. L. Hawksworth, A. Millanes, M. C. Molina, M. Wedin, T. Ahti, A. Aptroot, E. Barreno, F. Bungartz, S. Calvelo, M. Candan, M. Cole, D. Ertz, B. Goffinet, L. Lindblom, R. Lucking, F. Lutzoni, J. E. Mattsson, M. I. Messuti, J. Miadlikowska, M. P. Normore, V. J. Rico, H. J. M. Sipman, I. Schmitt, T. Spribille, A. Thell, G. Thor, D. K. Upreti, H. T. H. T. Lumbsch, Phylogenetic generic classification of parmelioid lichens (Parmeliaceae, Ascomycota) based on molecular, morphological and chemical evidence, Taxon. 59 (2010) 1735-1753.

[27] M. P. Gomez - Serranillos, C. Fernandez - Moriano, E. Gonzalez - Burgos, P. K. Divakar, A. Crespo, Parmeliaceae family: phytochemistry, pharmacological potential and phylogenetic features, RSC Adv. 4 (2014) 59017-59047. 
[28] R. Lücking, P. H. Brendan, D. L. Steven, The 2016 classification of lichenized fungi in the Ascomycota and Basidiomycota - Approaching one thousand genera, The Bryologist. 119 (2017) 361-416.

[29] P. Le Pogam, A. C. Le Lamer, B. Siva, B. Arnaud, G. Jérôme, J. Denis, R. Isabelle, F. Solenn, O. Walter, K. S. Babu, J. Bousyie, Minor Pyranonaphthoquinones from the Apothecia of the Lichen Ophioparma ventosa, J Nat Prod. 79 (2016) 10051011.

[30] S. Bandi, V. Arramshetti, P. Borra, D. R. Solipeta, J. Boustie, B. S. Bastien, N. Jain, P. Usha Rani, K. S. Babu, New seco-limonoids from Cipadessa baccifera: Isolation, structure determination, synthesis and their antiproliferative activities, Fitoterapia. 117 (2017) 34-40.

[31] A. Orange, P. W. James, F. J White, Microchemical methods for the identification of lichens. (2016) British Lichen Society, U.K.

[32] F. J. White, P. W. James, A new guide to microchemical techniques for the identification of lichen substances, Bulletin British Lichen Society. 57 (1985) 1-41.

[33] S. Mohabe, D. B. Anjali, A. M. Reddy, S. Nayaka, P. S. Chandramati, An appraisal of lichen biota in Chittoor district of Andhra Pradesh, India. In: Pullaiah T, Sandhya R (eds) Biodiversity in India. 8 (2016a) 247-296.

[34] D. D. Awasthi, A Compendium of the Macrolichens from India, Nepal and Sri Lanka. (2007) Bishen Singh Mahendra Pal Singh, Dehra Dun.

[35] P. K. Divakar, D. K. Upreti, Parmelioid Lichens in India (A Revisionary Study). 38 (2005) Bishen Singh Mahendra Pal Singh, Dehra Dun. 
[36] U. Jayalal, P. K. Divakar, S. Joshi, O. Soon-Ok, Y. J. Koh, H. Jae-Seoun, The Lichen Genus Parmotrema in South Korea. Mycobiol. 41 (2013) 25-36.

[37] A. L. Capriotti, C. Cavaliere, P. Giansanti, R. Gubbiotti, R. Samperi, A. Laganà, Recent developments in matrix solid-phase dispersion extraction, J Chromatogr A. 1217 (2010) 2521-2532.

[38] U. Priyanka, A. Anand, K. Bhargavi, A. Zehra, A. K. Tiwari, Presence of postprandial antidysmetabolic and antioxidative stress properties in aqueous methanol extract of seeds and tuber of aquatic food plant Nymphaea nouchali (Burm.f.), Food Sci Technol. 2 (2016) 1-9.

[39] B. Poornima, D. A. Kumar, B. Siva, A. Venkanna, P. R. Vadaparthi, K. Kumar K, A. K. Tiwari, K. S. Babu, Advanced glycation end-products inhibitors isolated from Schisandra grandiflora, Nat Prod Res. 30 (2016) 493-496.

[40] L. Séro, L. Sanguinet, P. Blanchard, B. T. Dang, S. Morel, P. Richomme P, Tuning a 96well microtiter plate fluorescence - based assay to identify AGE inhibitors in crude plant extracts, Molecules. 18 (2013) 14320-14339.

[41] S. G. Musharraf, N. Kanwal, M. Vinitha, M. Thadhani, I. Choudhary, Rapid identification of lichen compounds based on the structure-fragmentation relationship using ESI-MS/MS analysis, Anal Methods. 7 (2015) 6066-6076.

[42] M. J. Calcott, D. F. Ackerley, A. Knight, R. A. Keyzers, J. G. Owen, Secondary metabolism in the lichen symbiosis, Chem Soc Rev. 47 (2018) 1730-1760.

[43] T. H. Duong, W. Chavasiri, J. Boustie, K. P. P. Nguyen, New meta-depsidones and diphenyl ethers from the lichen Parmotrema tsavoense (Krong \& Swinscow) Krong \& Swinscow, Parmeliaceae, Tetrahedron 71 (2015) 9684-9691. 
[44] O. N. Castro, J. Benites, J. Rodilla, J. C. Santiago, M. Simirgiotis, B. Sepulveda, Metabolomic Analysis of the Lichen Everniopsis trulla using Ultra High Performance Liquid Chromatography-Quadrupole-Orbitrap Mass Spectrometry (UHPLC-Q-OT-MS), Chromatographia. 80 (2017) 967-973.

[45] B. L. C. Huynh, D. H. Le, Y. Takenaka, T. Tanahashi, K. P. P. Nguyen, New Phenolic compounds from the lichen Parmotrema praesorediosum (Nyl.) Hale (Parmeliaceae), Magn Reson Chem. 54 (2015) 81-87.

[46] B. L. C. Huynh, T. H. Duong, T. M. L. Do, T. G. Pinnock, L. M. Pratt, S. Yamamoto S, New $\gamma$ - Lactone Carboxylic acids from the Lichen Parmotrema praesorediosum (Nyl.) Hale, Parmeliaceae, Rec Nat Prod. 10 (2016) 332-340.

[47] S. Huneck, tert- Butanolysis of lichen depsides, Phytochemistry. 23 (1984) 2697-2698.

[48] J. A. Elix JA, Parmotrema. Flora of Australia, 55 (1994) 140-162.

[49] B. Winnem, Parmelia subgenus Amphigymnia in Ethiopia, Norwegian Journal of Botany. 22 (1975) 139-166.

[50] G. Holzmann, C. Leuckert, Applications of negative fast atom bombardment and MS/MS to screening of lichen compounds, Phytochemistry. 29 (1990) 2277-2283.

[51] E. S. W. Otter, Metabolic diversity of lichen forming ascomycetous fungi: culturing, polyketide and shikimate metabolite production, and PKS genes, Nat Prod Rep. 25 (2008) 188-200.

[52] D. Horhand, A. C. Le Lamer, J. Boustie, P. Uriac, N. Gouault, Separation of a mixture of paraconic acids from Cetraria islandica (L.) Ach. employing a fluorous tag-catch and release strategy. Tetrahedron Lett. 48 (2007) 6031-6033. 
[53] J. Asplund, A. Siegenthaler, Y. Gauslaa, Stimulated global warming increases usnic acid but perlatolic acid in the mat-forming terricolous lichen Cladonia stellaris, The Lichenologist. 49 (2017) 269-274.

[54] K. Marijana, R. Branislav, V. Jelena, Antioxidant properties of some lichen species, J Food Sci Technol. 48 (2011) 584-590.

[55] P. Salin Raj, A. Prathapan, J. Sebastian, A. K. Antony, M. P. Riya, M. R. Rani, H. Biju, S. Priya, K. G. Raghu, Parmotrema tinctorum exhibits antioxidant, antiglycation and inhibitory activities against aldose reductase and carbohydrate digestive enzymes: as in vitro study, Nat Prod Res. 28 (2014) 1480-1484.

[56] M. T. Vinitha, K. Veranja, Potential of Lichen Compounds as Antidiabetic Agents with Antioxidative Properties: A Review, Oxid Med Cell Longev. 2017 (2017) 1-10.

[57] R. Re, N. Pellegrini, A. Proteggente, A. Pannala, M. Yang, C. Rice-Evans, Antioxidant activity applying an improved ABTS radical cation decolorization assay, Free Radic Biol Med. 26 (1999) 1231-1237.

[58] T. I. B. Lopes, R. G. Coelho, N. C. Yoshida, N. K. Honda, Radical-scavenging activity of orsellinates, Chem Pharm Bull. 56 (2008) 1551-1554.

[59] F. Giacco, M. Brownlee, Oxidative stress and diabetic complications, Circ Res. 107 (2010) 1058-1070.

[60] B. Sottero, S. Gargiulo, I. Russo, C. Barale, G. Poli, F. Cavalot, Postprandial dysmetabolism and oxidative stress in type 2 diabetes: Pathogenetic mechanisms and therapeutic strategies, Med Res Rev. 35 (2015) 968-1031.

[61] M. A. Grillo, S. Colombatto, Advanced glycation end products (AGEs): Involvement in aging and in neurodegenerative diseases, Amino Acids. 35 (2008) 29-36. 
[62] D. Vashishth, Advanced Glycation End-products and Bone Fractures, IBMS BoneKEy. 6 (2009) 268-278.

[63] G. Rambold, E. Davydov, J. A. Elix, T. H. Nash III, C. H. Scheidegger, L. Zedda (eds), LIAS light - A database for rapid identification of Lichens, (2001) liaslight.lias.net/. 


\section{Figure Legend:}

Fig. 1: Chemical structures of identified compounds

Fig. 2: A. Comparison of extract yields in Cold and Hot (Ultra sonication) for solvent optimization from non polar to polar B. Comparison of MSPD [RP $\left.\mathrm{SiO}_{2}(1: 2)\right]$ with cold and ultra sonication methods C. Comparison of sorbent to sample ratio

Fig. 3: TIC Spectra (LC-QToF-MS/MS) for A) Parmotrema tinctorum, B) P. andinum, C) $P$. praesorediosum, D) $P$. grayanum, E) $P$. austrosinense acetone extracts

Fig. 4: MS/MS Fragmentation pathway for Depside type (1-11) compounds

Fig. 5: MS/MS Fragmentation pathway for Depsidone type (12-22) compounds

Fig. 6: MS/MS Fragmentation pathway for Monophenolic type (23-29) compounds

Fig. 7: MS/MS Fragmentation pathway for Paraconic acid type (30-47) compounds 
<smiles>[R]Oc1c([R])c([R])c(C(=O)O)c(O)c1OC(=O)c1c([R])c([R6])c([R20])c([R])c1O</smiles>

1: $\mathrm{R}_{1}=\mathrm{Me}, \mathrm{R}_{2}=\mathrm{H}, \mathrm{R}_{3}=\mathrm{H}, \mathrm{R}_{4}=\mathrm{H}, \mathrm{R}_{5}=\mathrm{H}, \mathrm{R}_{6}=\mathrm{H}, \mathrm{R}_{7}=\mathrm{CH}_{3}$

6: $\mathrm{R}_{1}=$

10: $\mathrm{R}_{1}=\mathrm{CHO}, \mathrm{R}_{2}=\mathrm{H}, \mathrm{R}_{3}=\mathrm{H}, \mathrm{R}_{4}=\mathrm{H}, \mathrm{R}_{5}=\mathrm{H}, \mathrm{R}_{6}=\mathrm{H}, \mathrm{R}_{7}=\mathrm{CH}_{3}$<smiles>[R]c1cc(OC(=O)c2c([R3])cc(OC)cc2O)cc(O)c1[R]</smiles>

5: $\mathrm{R}_{1}=\mathrm{COOH}, \mathrm{R}_{2}=\mathrm{C}_{3} \mathrm{H}_{7}, \mathrm{R}_{3}=\mathrm{C}_{3} \mathrm{H}_{7}$ 9: $\mathrm{R}_{1}=\mathrm{H}, \mathrm{R}_{2}=\mathrm{C}_{5} \mathrm{H}_{11}, \mathrm{R}_{3}=\mathrm{C}_{3} \mathrm{H}_{7}$<smiles>[R]c1cc(C)c2c(c1[R2])Oc1c(c([R3])c(O)c3c1C(O)OC3=O)OC2=O</smiles>

12: $\mathrm{R}_{1}: \mathrm{OH}, \mathrm{R}_{2}=\mathrm{CH}_{2} \mathrm{OH}, \mathrm{R}_{3}=\mathrm{CH}_{2} \mathrm{OH}$, 13: $\mathrm{R}_{1}=\mathrm{OMe}, \mathrm{R}_{2}=\mathrm{CHO}, \mathrm{R}_{2}=\mathrm{CH}_{2} \mathrm{OH}$, 14: $\mathrm{R}_{1}=\mathrm{OH}, \mathrm{R}_{2}=\mathrm{CHO}, \mathrm{R}_{3}=\mathrm{CH}_{2} \mathrm{OH}$ 15: $\mathrm{R}_{1}=\mathrm{OMe}, \mathrm{R}_{2}=\mathrm{CHO}, \mathrm{R}_{3}=\mathrm{Me}$ 16: $\mathrm{R}_{1}: \mathrm{OH}, \mathrm{R}_{2}=\mathrm{CHO}, \mathrm{R}_{3}=\mathrm{Me}$ 17: $\mathrm{OMe}, \mathrm{R}_{2}=\mathrm{Me}, \mathrm{R}_{3}=\mathrm{CH}_{2} \mathrm{OH}$,

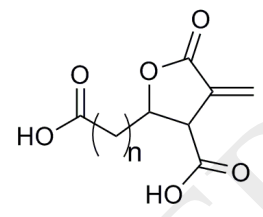

$30: n=14$

45: $n=13$

$46: n=16$

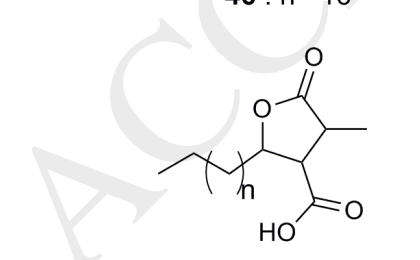

$35: n=11$

$39: n=13$

$42: n=9$<smiles>C=C1C(=O)OC(CCC)C1C(=O)O</smiles>

$36: n=11$

$40: n=13$<smiles>[R1]c1c(O)c(C(=O)O)c(C)c2c1OC(=O)c1c(C)cc(O)c([R2])c1O2</smiles>

18: $\mathrm{R}_{1}=\mathrm{CH} 2 \mathrm{O}, \mathrm{R}_{2}=\mathrm{Me}$<smiles>[R20]C(=O)c1c([R3])cc(O)c([R1])c1O</smiles>

24: $\mathrm{R} 1=\mathrm{H}, \mathrm{R} 2=\mathrm{H}, \mathrm{R} 3=\mathrm{CH}_{3}$

25: $\mathrm{R} 1=\mathrm{CHO}, \mathrm{R} 2=\mathrm{H}, \mathrm{R} 3=\mathrm{CH}_{3}$

26: $\mathrm{R} 1=\mathrm{CH}_{3}, \mathrm{R} 2=\mathrm{CH}_{3}, \mathrm{R} 3=\mathrm{CH}_{3}$

27: $\mathrm{R} 1=\mathrm{H}, \mathrm{R} 2=\mathrm{H}, \mathrm{R} 3=\mathrm{CHO}$

28: $\mathrm{R} 1=\mathrm{H}, \mathrm{R} 2=\mathrm{H}, \mathrm{R} 3=\mathrm{CH} 2 \mathrm{OH}$

29: $\mathrm{R} 1=\mathrm{CHO}, \mathrm{R} 2=\mathrm{CH}_{3}, \mathrm{R} 3=\mathrm{CH}_{3}$<smiles>O=C(O[Tl])c1ccccc1O</smiles>

23: $R_{1}=H$

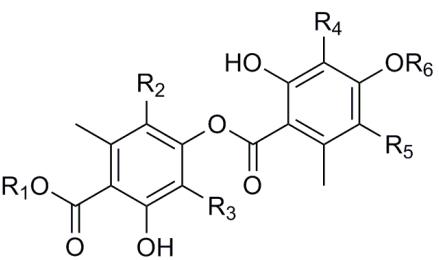

2: $\mathrm{R}_{1}=\mathrm{H}, \mathrm{R}_{2}=\mathrm{H}, \mathrm{R}_{3}=\mathrm{H}, \mathrm{R}_{4}=\mathrm{H}, \mathrm{R}_{5}=\mathrm{H}, \mathrm{R}_{6}=\mathrm{H}$ 3: $\mathrm{R}_{1}=\mathrm{H}, \mathrm{R}_{2}=\mathrm{H}, \mathrm{R}_{3}=\mathrm{H}, \mathrm{R}_{4}=\mathrm{H}, \mathrm{R}_{5}=\mathrm{H}, \mathrm{R}_{6}=\mathrm{HO}_{\text {1 }} \mathrm{OH}$

4: $\mathrm{R}_{1}=\mathrm{Me}, \mathrm{R}_{2}=\mathrm{H}, \mathrm{R}_{3}=\mathrm{Me}, \mathrm{R}_{4}=\mathrm{COOH}, \mathrm{R}_{5}=\mathrm{H}, \mathrm{R}_{6}=\mathrm{H}$ 7: $\mathrm{R}_{1}=\mathrm{Me}, \mathrm{R}_{2}=\mathrm{H}, \mathrm{R}_{3}=\mathrm{Me}, \mathrm{R}_{4}=\mathrm{CHO}, \mathrm{R}_{5}=\mathrm{H}, \mathrm{R}_{6}=\mathrm{H}$ 8: $\mathrm{R}_{1}=\mathrm{Me}, \mathrm{R}_{2}=\mathrm{H}, \mathrm{R}_{3}=\mathrm{Me}, \mathrm{R}_{4}=\mathrm{CHO}, \mathrm{R}_{5}=\mathrm{Cl}, \mathrm{R}_{6}=\mathrm{H}$

11: $R_{1}=H, R_{2}=H, R_{3}=H, R_{4}=H, R_{5}=H, R_{6}=$

19: $\mathrm{R}_{1}=\stackrel{\mathrm{O}}{\sim}, \mathrm{R}_{2}=\mathrm{H}, \mathrm{R}_{3}=\mathrm{OH}, \mathrm{R}_{4}=\mathrm{H}, \mathrm{R}_{5}=: \leadsto$ 20,21: $R_{1}=:_{\mathrm{O}} \mathrm{R}_{2}=\mathrm{H}, \mathrm{R}_{3}=\mathrm{OH}, \mathrm{R}_{4}=\mathrm{COOH}, \mathrm{R}_{5}=\mathrm{C}_{\mathrm{O}}$ 22: $\mathrm{R}_{1}=\mathrm{O}, \mathrm{R}_{2}=\mathrm{Me}, \mathrm{R}_{3}=\mathrm{OH}, \mathrm{R}_{4}=\mathrm{COOH}, \mathrm{R}_{5}=: \leadsto$<smiles>[R20]c1cc([R])c2c(c1)Oc1c(cc([R3])c([R])c1[R])OC2=O</smiles><smiles>CC1=C(C(=O)O)C(CCC(=O)O)OC1=O</smiles><smiles>C=C1OC(CCCCC(C)C)C(C(=O)O)=C1C</smiles><smiles>C=C1C(=O)OC([Y](C)(C)CC)=C1C(=O)O</smiles><smiles>[H][Y8]([H])([18F])C1OC(=O)C(=C)C1C(=O)O</smiles>

$44: n=9$

33: $n=13$

Fig. 1. 


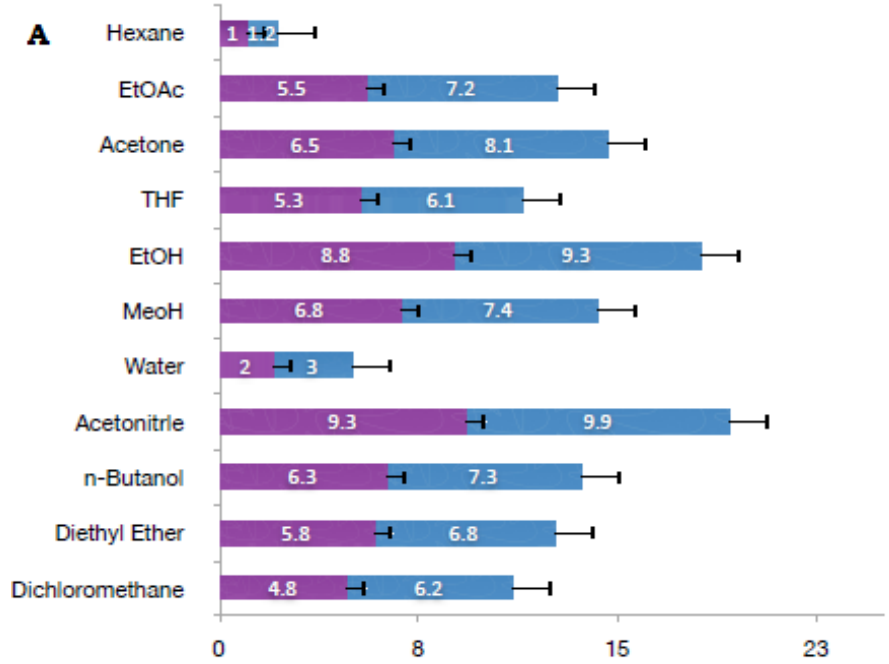

B

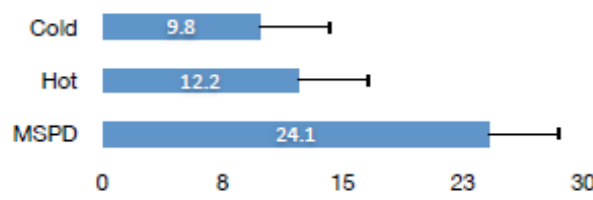

C

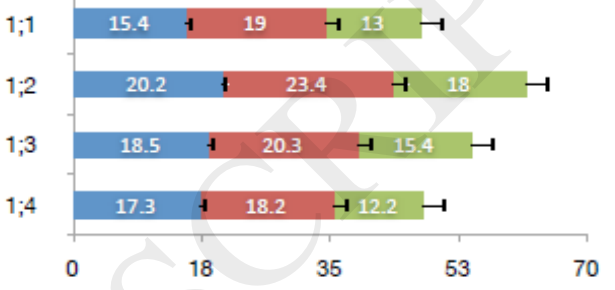

Fig. 2. 

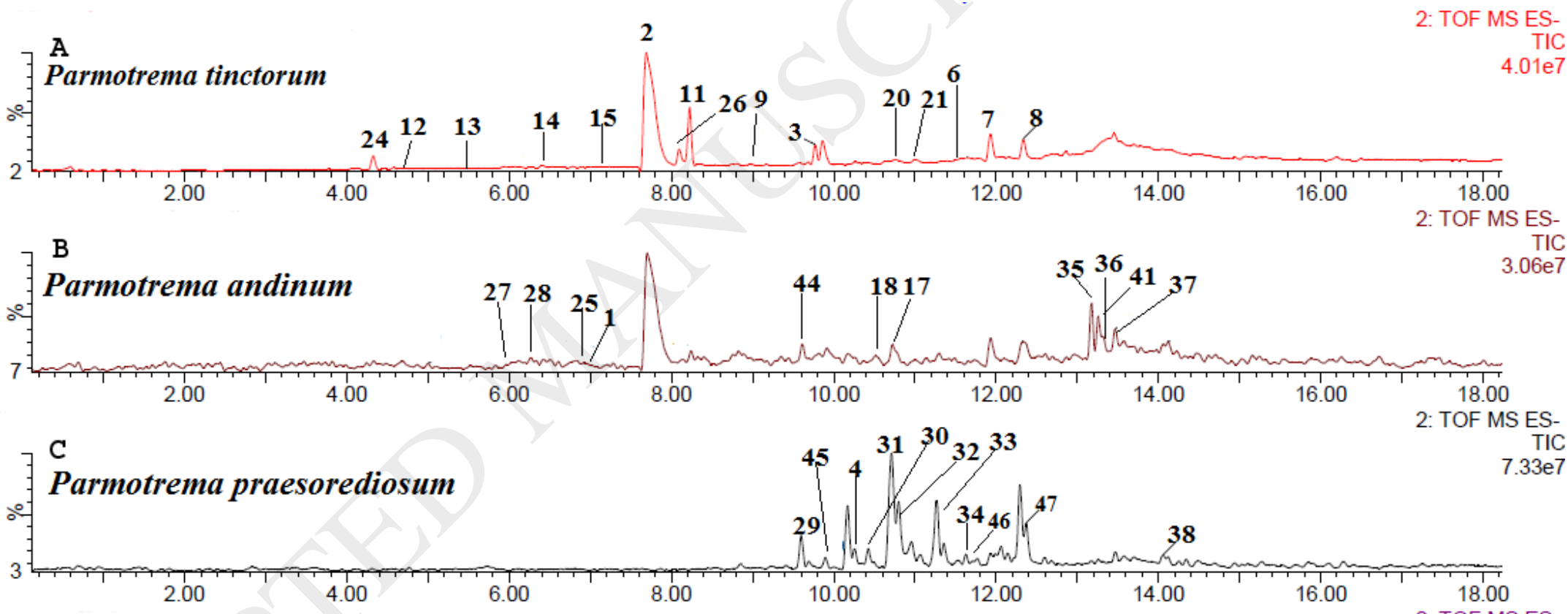

TIC

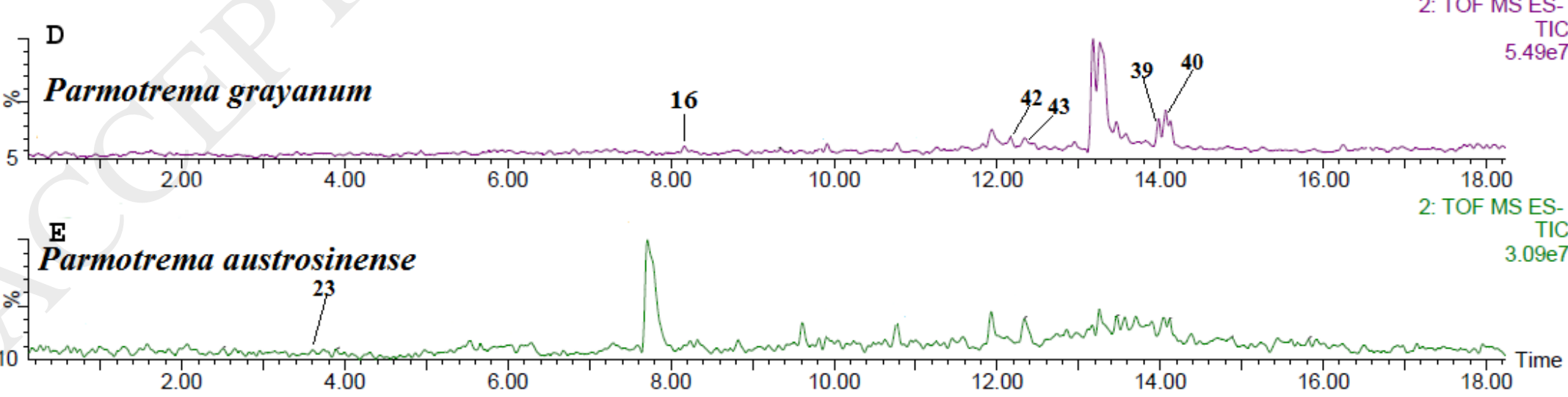

Fig. 3 


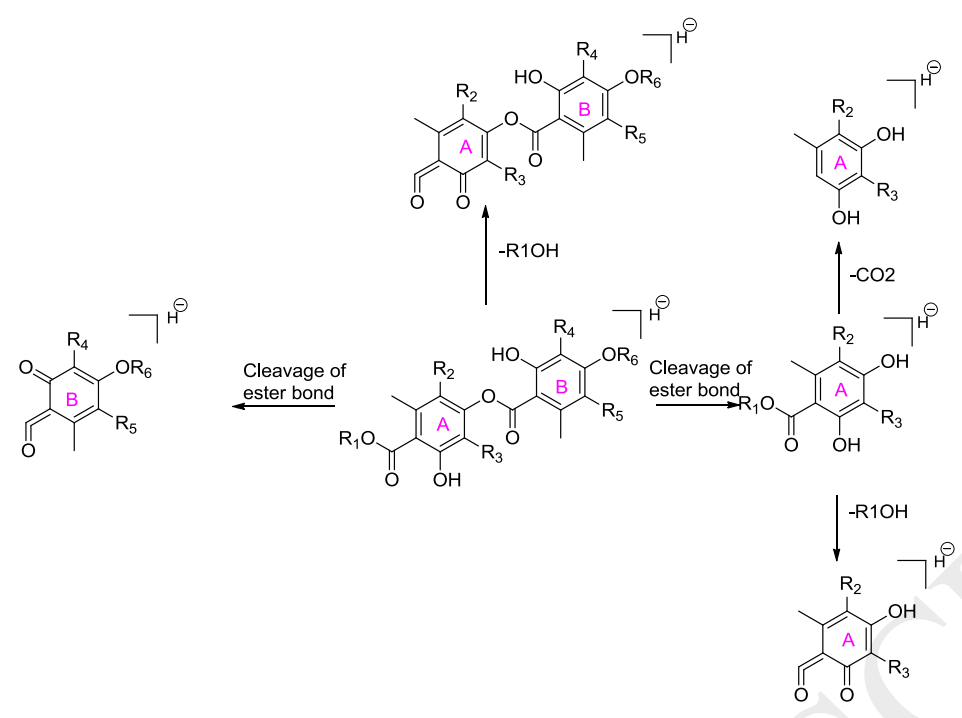

Fig. 4. 


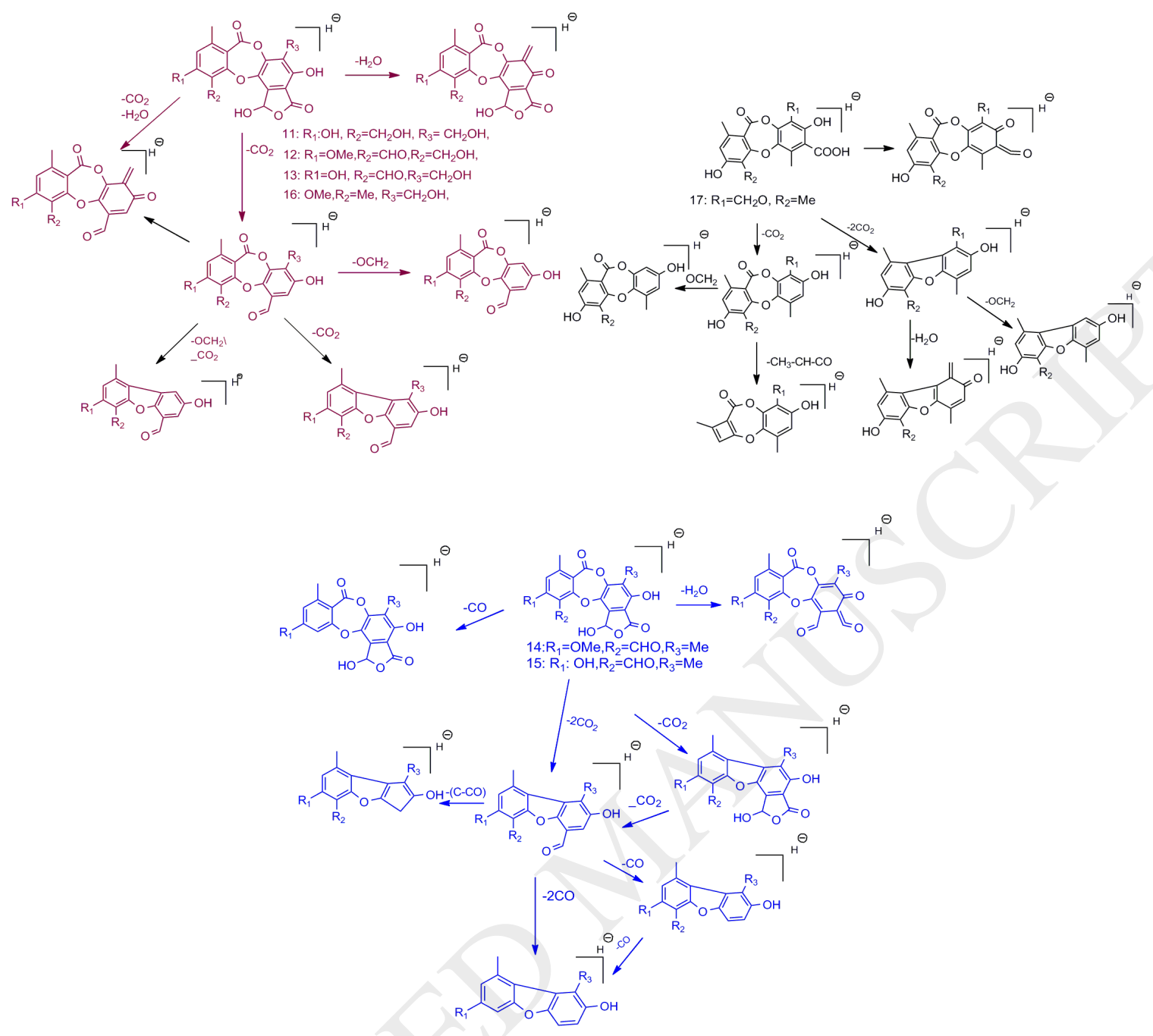

Fig. 5. 


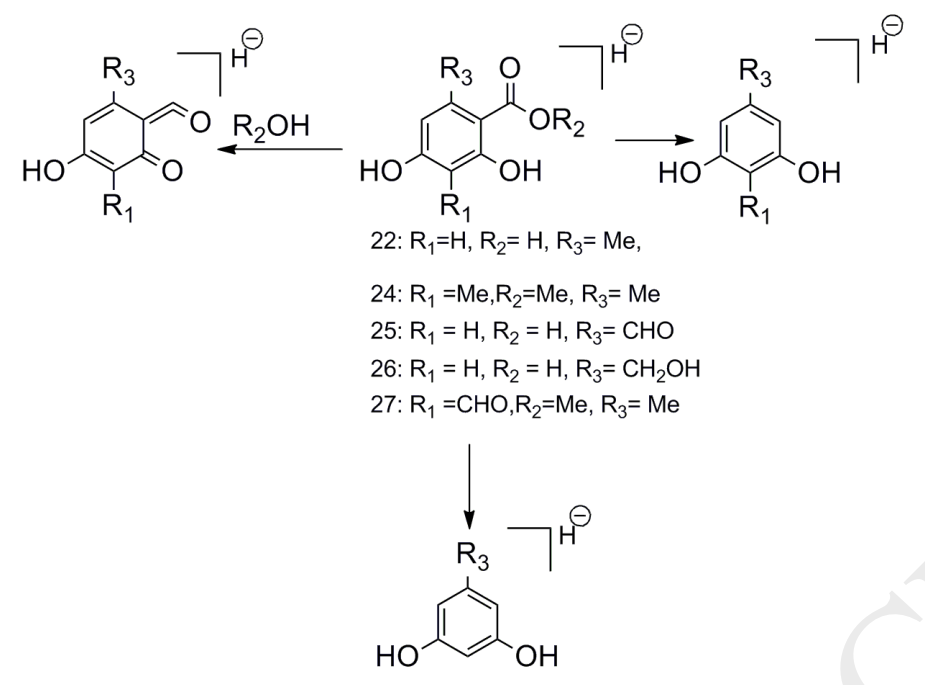

Fig. 6.

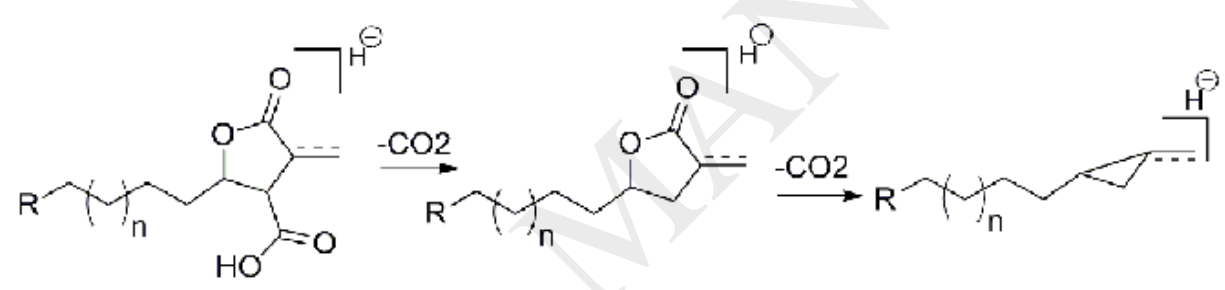

Fig. 7. 


\section{Table 1}

LC-QToF-MS ${ }^{\mathrm{e}}$ data of compounds from acetonitrile extracts of lichens (PT, PA, PP, PG and PS, see footnote) and their product ions

\begin{tabular}{|c|c|c|c|c|c|c|c|c|c|c|c|c|}
\hline Cp & RRt & {$[\mathrm{M}-\mathrm{H}]^{-}$} & Mol Formula & Error & UV $\lambda_{\max }$ & Product Ions $(\mathrm{m} / \mathrm{z})$ & Putative & \multicolumn{5}{|c|}{ Samples } \\
\hline No & & & & & & & & PT & PA & PP & PG & PS \\
\hline \multicolumn{13}{|c|}{ Depsides } \\
\hline 1 & 6.90 & 333.0611 & $\mathrm{C}_{16} \mathrm{H}_{13} \mathrm{O}_{8}$ & 0.3 & 221.00 & 183.0297, 167.0342 & Papulosic acid & - & + & - & - & - \\
\hline 2 & 7.71 & 317.0663 & $\mathrm{C}_{16} \mathrm{H}_{13} \mathrm{O}_{7}$ & 0.6 & 268.00 & $\begin{array}{c}167.0354,149.0238 \\
123.0446,105.0341\end{array}$ & Lecanoric acid & $+*$ & $+*$ & - & - & $+*$ \\
\hline 3 & 9.79 & 467.0978 & $\mathrm{C}_{24} \mathrm{H}_{19} \mathrm{O}_{10}$ & 0.0 & 268.00 & $\begin{array}{c}317.0662,167.0345 \\
149.0238,123.0444\end{array}$ & Gyrophoric Acid & + & - & - & - & - \\
\hline 4 & 10.26 & 389.0869 & $\mathrm{C}_{19} \mathrm{H}_{17} \mathrm{O}_{9}$ & -1.0 & 222.00 & $\begin{array}{c}193.0137,163.0396 \\
149.0240\end{array}$ & Cladonioidesin & - & - & + & + & + \\
\hline 5 & 11.53 & 387.1441 & $\mathrm{C}_{21} \mathrm{H}_{23} \mathrm{O}_{7}$ & -0.8 & 223.00 & $\begin{array}{c}195.0659,177.0552, \\
151.0777,133.0657\end{array}$ & Divaricatic acid & - & - & + & - & - \\
\hline 6 & 11.58 & 417.1542 & $\mathrm{C}_{22} \mathrm{H}_{25} \mathrm{O}_{8}$ & -1.7 & 223.00 & $\begin{array}{c}225.0762,209.0813 \\
165.0914,150.0678 \\
137.0239\end{array}$ & Sekikaic acid & + & - & - & - & - \\
\hline 7 & 11.94 & 373.0921 & $\mathrm{C}_{19} \mathrm{H}_{17} \mathrm{O}_{8}$ & -0.5 & $\begin{array}{l}212.00 \\
249.00\end{array}$ & $\begin{array}{l}195.0656,177.0188, \\
163.0395,133.0289 \\
119.0497,105.0342\end{array}$ & Atranorin & $t^{*}$ & $+*$ & $+*$ & $+*$ & $+*$ \\
\hline 8 & 12.34 & 407.0535 & $\mathrm{C}_{19} \mathrm{H}_{16} \mathrm{O}_{8} \mathrm{Cl}$ & 0.1 & 216.00 & $\begin{array}{l}331.0375,210.9802 \\
195.0661,163.0397 \\
138.9953,119.0498\end{array}$ & Chloratranorin & $+*$ & $+*$ & $+*$ & $+*$ & $+*$ \\
\hline 9 & 9.00 & 371.1855 & $\mathrm{C}_{22} \mathrm{H}_{27} \mathrm{O}_{5}$ & -0.8 & 222.00 & $353.1750,309.1698,193.0864$ & $\begin{array}{c}\text { Decarboxy } \\
\text { stenosporic acid }\end{array}$ & + & - & - & - & - \\
\hline 10 & 6.11 & 347.0405 & $\mathrm{C}_{16} \mathrm{H}_{11} \mathrm{O}_{9}$ & 0.6 & 220.00 & $197.0083,153.0190$ & $\begin{array}{l}\text { Papulosic acid } \\
\text { derivative }\end{array}$ & - & + & - & - & - \\
\hline 11 & 8.22 & 617.1285 & $\mathrm{C}_{32} \mathrm{H}_{25} \mathrm{O}_{13}$ & -1.6 & 219.00 & $\begin{array}{c}467.0976,339.0472, \\
317.0660,167.0345, \\
149.0236,123.0444\end{array}$ & $\begin{array}{l}\text { Orsellinylgyrophor } \\
\text { ate }\end{array}$ & + & - & - & - & - \\
\hline \multicolumn{13}{|c|}{ Depsidones } \\
\hline 12 & 4.70 & 389.0508 & $\mathrm{C}_{18} \mathrm{H}_{13} \mathrm{O}_{10}$ & 0.3 & 217.00 & $\begin{array}{c}\text { 371.0401, 345.0607, } \\
327.0505,309.0401, \\
297.0401,253.0504, \\
227.0351,209.0605,121.0297\end{array}$ & Consalazinic acid & + & - & - & - & - \\
\hline
\end{tabular}




\begin{tabular}{|c|c|c|c|c|c|c|c|c|c|c|c|c|}
\hline 13 & 5.59 & 401.0505 & $\mathrm{C}_{19} \mathrm{H}_{13} \mathrm{O}_{10}$ & -1.0 & 219.00 & $\begin{array}{c}373.0555,357.0608, \\
329.0659,283.0606, \\
255.0661,227.0710,121.0292\end{array}$ & Constictic acid & + & - & - & - & - \\
\hline 14 & 6.42 & 387.0357 & $\mathrm{C}_{18} \mathrm{H}_{11} \mathrm{O}_{10}$ & 1.3 & 237.00 & $\begin{array}{c}343.0455,325.0348, \\
313.0347,299.0554, \\
269.0452,243.0296, \\
227.0346,151.0396,121.0290\end{array}$ & Salazinic acid & $+*$ & - & - & - & - \\
\hline 15 & 7.19 & 385.0558 & $\mathrm{C}_{19} \mathrm{H}_{13} \mathrm{O}_{9}$ & -0.5 & 218.00 & $\begin{array}{c}341.0658,297.0760 \\
267.0308,165.0550,121.0294\end{array}$ & Stictic acid & + & - & - & + & - \\
\hline 16 & 8.16 & 371.0403 & $\mathrm{C}_{18} \mathrm{H}_{11} \mathrm{O}_{9}$ & 0.0 & 221.00 & $\begin{array}{l}327.0505,283.0608 \\
255.0658,243.0297 \\
227.0350,151.0396\end{array}$ & Norstictic acid & - & - & - & + & - \\
\hline 17 & 10.77 & 387.0710 & $\mathrm{C}_{19} \mathrm{H}_{15} \mathrm{O}_{9}$ & -1.6 & 222.00 & $\begin{array}{c}355.0451,193.0135, \\
165.0184,137.0238,121.0292\end{array}$ & Hypoconstictic acid & - & + & - & + & + \\
\hline 18 & 10.51 & 359.0774 & $\mathrm{C}_{18} \mathrm{H}_{15} \mathrm{O}_{8}$ & 1.9 & 222.00 & $195.0299,181.0504,137.0601$ & $\begin{array}{l}\text { Conhypoprotoce- } \\
\text { traric acid }\end{array}$ & - & + & + & + & - \\
\hline 19 & 10.62 & 397.1665 & $\mathrm{C}_{23} \mathrm{H}_{25} \mathrm{O}_{6}$ & 3.5 & $\begin{array}{l}219.00 \\
269.00\end{array}$ & $\begin{array}{c}369.1702,353.1758, \\
329.1757,313.1078 \\
296.1051,201.0553,161.0238\end{array}$ & Norlobaridone & + & - & - & - & - \\
\hline 20 & 10.73 & 511.1965 & $\mathrm{C}_{28} \mathrm{H}_{31} \mathrm{O}_{9}$ & -0.6 & 223.00 & $\begin{array}{l}\text { 493.1854, 467.2065, } \\
449.1956,381.2268 \\
369.1330,337.2375 \\
319.2273,293.2480 \\
247.0971,193.0137\end{array}$ & $\alpha$-Alectoronic acid & + & - & - & - & - \\
\hline 21 & 11.06 & & $\mathrm{C}_{28} \mathrm{H}_{31} \mathrm{O}_{9}$ & -0.7 & 222.00 & $\begin{array}{l}493.1854,467.2065, \\
449.1956,381.2268, \\
369.1330,337.2375, \\
319.2273,293.2480, \\
247.0971,193.0137\end{array}$ & $\begin{array}{l}\alpha \text {-Alectoronic acid } \\
\text { Isomer }\end{array}$ & + & - & - & - & - \\
\hline 22 & 11.36 & 455.1703 & $\mathrm{C}_{25} \mathrm{H}_{27} \mathrm{O}_{8}$ & -0.7 & 223.00 & $\begin{array}{l}423.1439,379.1545 \\
355.1542,193.0863\end{array}$ & Lobaric acid & + & - & - & - & - \\
\hline \multicolumn{13}{|c|}{ Mono phenolics } \\
\hline 23 & 3.49 & 137.0244 & $\mathrm{C}_{7} \mathrm{H}_{5} \mathrm{O}_{3}$ & 3.6 & 200.00 & 109.0303 & $\begin{array}{l}\text { Hydroxy benzoic } \\
\text { acid }\end{array}$ & - & - & - & - & + \\
\hline 24 & 4.34 & 167.0340 & $\mathrm{C}_{8} \mathrm{H}_{7} \mathrm{O}_{4}$ & -2.4 & 218.00 & $123.0446(\mathrm{C} 7 \mathrm{H} 7 \mathrm{O} 2)$ & Orsellinic Acid & $+*$ & + & - & - & + \\
\hline 25 & 6.79 & 195.0293 & $\mathrm{C}_{9} \mathrm{H}_{7} \mathrm{O}_{5}$ & 0.0 & 221.00 & $151.0394,123.0442$ & Haematommic acid & - & + & + & + & - \\
\hline 26 & 7.87 & 181.0502 & $\mathrm{C}_{9} \mathrm{H}_{9} \mathrm{O}_{4}$ & 0.6 & 221.00 & $163.0393,137.0600,119.0495$ & $\begin{array}{l}\text { Methyl } \beta \text { - } \\
\text { orsellinate }\end{array}$ & $+*$ & + & $+*$ & + & + \\
\hline 27 & 5.96 & 181.0139 & $\mathrm{C}_{8} \mathrm{H}_{5} \mathrm{O}_{5}$ & 1.1 & 220.00 & $163.0032,137.0242$ & $\begin{array}{c}\text { Demethyliso } \\
\text { haematommate }\end{array}$ & - & + & - & - & - \\
\hline
\end{tabular}




\begin{tabular}{|c|c|c|c|c|c|c|c|c|c|c|c|c|}
\hline 29 & 9.60 & 209.0450 & $\mathrm{C}_{10} \mathrm{H}_{9} \mathrm{O}_{5}$ & 0.0 & 222.00 & $165.0193,139.0403$ & $\begin{array}{c}\text { Dihydro } \\
\text { demethyliso } \\
\text { haematommate } \\
\text { Methyl- } \\
\text { haematommate }\end{array}$ & - & + & + & + & - \\
\hline \multicolumn{13}{|c|}{ Paraconic and Aliphatic Acids } \\
\hline 30 & 10.42 & 381.2275 & $\mathrm{C}_{21} \mathrm{H}_{33} \mathrm{O}_{6}$ & -0.5 & 222.00 & $\begin{array}{c}337.2377,319.2271, \\
315.2525,293.2480,275.2372\end{array}$ & Praesorediosic acid & - & - & $+*$ & - & - \\
\hline 31 & 10.72 & 381.2277 & $\mathrm{C}_{21} \mathrm{H}_{33} \mathrm{O}_{6}$ & 0.0 & 221.00 & $\begin{array}{l}337.2377,319.2272 \\
293.2481,275.2375\end{array}$ & $\begin{array}{l}\text { Protopraesorediosic } \\
\text { acid }\end{array}$ & - & + & $+*$ & - & - \\
\hline 32 & 10.96 & 323.2578 & $\mathrm{C}_{20} \mathrm{H}_{35} \mathrm{O}_{3}$ & -2.5 & 222.00 & $\begin{array}{c}\text { 277.2524, 263.2368 } \\
\text { 235.2421, 181.0497 } \\
177.0183,149.0236\end{array}$ & $\begin{array}{l}\text { Aliphatic acid } \\
\text { (unidentified) }\end{array}$ & - & - & + & - & - \\
\hline 33 & 11.27 & 365.2340 & $\mathrm{C}_{21} \mathrm{H}_{33} \mathrm{O}_{5}$ & 3.3 & 221.00 & $\begin{array}{c}321.2444,307.2635 \\
291.2320,261.2215 \\
183.1746,169.1591,123.0811\end{array}$ & Muronic acid & - & - & + & - & - \\
\hline 34 & 11.68 & 381.2271 & $\mathrm{C}_{21} \mathrm{H}_{33} \mathrm{O}_{6}$ & -1.6 & 223.00 & $\begin{array}{c}337.2376,295.2270 \\
277.2169,221.2274,149.0085\end{array}$ & $\begin{array}{l}\text { 19-acetoxy } \\
\text { protolichesterinic } \\
\text { acid }\end{array}$ & - & - & + & - & - \\
\hline 35 & 13.17 & 325.2381 & $\mathrm{C}_{19} \mathrm{H}_{33} \mathrm{O}_{4}$ & 0.6 & 224.00 & $281.2497,137.1132$ & $\begin{array}{l}\text { Dihydro lichesterinic } \\
\text { acid }\end{array}$ & + & + & - & + & + \\
\hline 36 & 13.30 & 323.2225 & $\mathrm{C}_{19} \mathrm{H}_{31} \mathrm{O}_{4}$ & 0.9 & 224.00 & $267.2325,235.2428$ & $\begin{array}{c}\text { Licheterinic/ } \\
\text { Protolichesterinic } \\
\text { acid }\end{array}$ & + & + & - & $+*$ & + \\
\hline 37 & 13.47 & 279.2325 & $\mathrm{C}_{18} \mathrm{H}_{31} \mathrm{O}_{2}$ & 0.4 & $\begin{array}{c}\mathrm{UV} \\
\text { Inactive }\end{array}$ & $233.1156,211.1333,171.1023$ & Linoleic acid isomer & + & + & + & + & + \\
\hline 38 & 14.06 & 307.2635 & $\mathrm{C}_{20} \mathrm{H}_{35} \mathrm{O}_{2}$ & -0.7 & 225.42 & $255.2320,193.0500,181.0502$ & $\begin{array}{l}\text { Aliphatic acid } \\
\text { (unidentified) }\end{array}$ & - & - & + & + & + \\
\hline 39 & 13.98 & 353.2692 & $\mathrm{C}_{21} \mathrm{H}_{37} \mathrm{O}_{4}$ & 0.0 & $\begin{array}{c}\text { UV } \\
\text { Inactive }\end{array}$ & 309.2798, & $\begin{array}{l}\text { 19-ethyl } \\
\text { dihydrolichesterinic } \\
\text { acid }\end{array}$ & - & - & - & + & - \\
\hline 40 & 14.13 & 351.2533 & $\mathrm{C}_{21} \mathrm{H}_{35} \mathrm{O}_{4}$ & -0.6 & 225.42 & $295.2631,263.2735,171.1014$ & $\begin{array}{l}\text { 19-ethyl } \\
\text { protolichesterinic } \\
\text { acid }\end{array}$ & - & - & - & + & + \\
\hline 41 & 13.26 & 279.2329 & $\mathrm{C}_{18} \mathrm{H}_{31} \mathrm{O}_{2}$ & 1.8 & $\begin{array}{c}\mathrm{UV} \\
\text { Inactive }\end{array}$ & $\begin{array}{c}249.2224,223.0977 \\
205.0868,179.1069,121.0657\end{array}$ & Linoleic acid & - & + & - & + & + \\
\hline 42 & 12.17 & 297.2065 & $\mathrm{C}_{17} \mathrm{H}_{29} \mathrm{O}_{4}$ & -0.3 & 224.00 & 253.2167 & Nephrosteranic acid & - & - & - & + & - \\
\hline 43 & 12.26 & 295.1969 & $\mathrm{C}_{17} \mathrm{H}_{27} \mathrm{O}_{4}$ & 7.8 & 224.00 & $251.2007,177.0558,209.0825$ & $\begin{array}{l}\text { Nephrosterinic } \\
\text { acid }\end{array}$ & - & - & - & + & - \\
\hline 44 & 9.53 & 293.1747 & $\mathrm{C}_{17} \mathrm{H}_{25} \mathrm{O}_{4}$ & -2.0 & 222.00 & $249.1861,193.1590,136.0889$ & $\begin{array}{c}\text { Dehydro } \\
\text { nephrosterinic } \\
\text { acid }\end{array}$ & - & + & - & - & - \\
\hline
\end{tabular}




\begin{tabular}{|c|c|c|c|c|c|c|c|c|c|c|c|c|}
\hline 45 & 9.89 & 367.2117 & $\mathrm{C}_{20} \mathrm{H}_{31} \mathrm{O}_{6}$ & -1.1 & 222.00 & $\begin{array}{c}339.2172,323.2219 \\
305.2114,295.2273 \\
279.2372,221.2268,177.0551\end{array}$ & $\begin{array}{l}\text { Norprotopraeso } \\
\text { rediosic acid }\end{array}$ & - & - & + & - & - \\
\hline 46 & 11.77 & 409.2586 & $\mathrm{C}_{23} \mathrm{H}_{37} \mathrm{O}_{6}$ & -1.0 & 223.00 & $\begin{array}{c}387.2500,365.2683 \\
347.2583,321.2780 \\
279.2324\end{array}$ & $\begin{array}{l}\text { Dihydrovinapraeso } \\
\text { rediosic acid }\end{array}$ & - & - & + & - & - \\
\hline 47 & 12.36 & 393.2606 & $\mathrm{C}_{23} \mathrm{H}_{37} \mathrm{O}_{5}$ & -8.9 & 216.00 & $305.2840,293.1783,210.9793$ & $\begin{array}{c}\text { Vinapraesorediosic } \\
\text { acid A }\end{array}$ & - & - & $+*$ & - & - \\
\hline \multicolumn{13}{|c|}{ Unknown Compounds } \\
\hline 48 & 9.27 & 397.2224 & $\mathrm{C}_{21} \mathrm{H}_{33} \mathrm{O}_{7}$ & -0.5 & 222.00 & 353.2336, 335.2217, & Unknown & - & - & + & - & - \\
\hline 49 & 9.92 & 549.3995 & $\mathrm{C}_{36} \mathrm{H}_{53} \mathrm{O}_{4}$ & 9.3 & 222.00 & $\begin{array}{c}281.2116,255.1962,141.0192 \\
503.3982,461.3831, \\
443.3732 .317 .0656,193.0196\end{array}$ & Unknown & - & + & - & + & - \\
\hline $\mathbf{5 0}$ & 8.86 & 225.0398 & $\mathrm{C}_{10} \mathrm{H}_{9} \mathrm{O}_{6}$ & -0.4 & 222.00 & $\begin{array}{l}195.0292,193.0137 \\
177.0187,149.0236\end{array}$ & Unknown & - & - & + & + & - \\
\hline 51 & 9.41 & 437.0272 & $\mathrm{C}_{19} \mathrm{H}_{14} \mathrm{O}_{10} \mathrm{Cl}$ & -0.7 & 222.00 & $\begin{array}{c}228.9904,210.9799, \\
193.0137,166.9900,138.9952\end{array}$ & Unknown & - & - & + & - & - \\
\hline 52 & 9.61 & 643.1267 & $\mathrm{C}_{30} \mathrm{H}_{27} \mathrm{O}_{16}$ & -5.0 & 222.00 & $493.0945,343.0630$ & Unknown & - & + & - & - & + \\
\hline 53 & 9.82 & 517.3731 & $\mathrm{C}_{28} \mathrm{H}_{53} \mathrm{O}_{8}$ & -1.7 & 222.00 & $\begin{array}{l}491.2653,457.3515 \\
179.0342,135.0446\end{array}$ & Unknown & - & - & - & - & + \\
\hline 54 & 9.84 & 179.0343 & $\mathrm{C}_{9} \mathrm{H}_{7} \mathrm{O}_{4}$ & -0.6 & 221.00 & $135.0446,105.0346$ & Unknown & - & - & + & + & - \\
\hline 55 & 12.60 & 605.2387 & $\mathrm{C}_{34} \mathrm{H}_{37} \mathrm{O}_{10}$ & 0.0 & 224.42 & 529.2233 & Unknown & - & + & + & - & - \\
\hline 56 & 13.40 & 527.3744 & $\mathrm{C}_{33} \mathrm{H}_{51} \mathrm{O}_{5}$ & 1.5 & $\begin{array}{c}\mathrm{UV} \\
\text { Inactive }\end{array}$ & 297.2417 & Unknown & - & + & - & - & - \\
\hline 57 & 13.70 & 591.2599 & $\mathrm{C}_{34} \mathrm{H}_{39} \mathrm{O}_{9}$ & 0.8 & 225.42 & $\begin{array}{l}\text { 559.2332, 537.2253, } \\
515.2441,337.2377, \\
299.2582,293.2476\end{array}$ & Unknown & - & - & + & + & + \\
\hline
\end{tabular}

(PT - P. tinctorum, PA - P. andinum, PP - P. praesorediosum, PG - P. grayanum, PS - P. austrosinense)

* Already described compound in the species by usual approaches in lichenology [24,63] 


\section{Table 2}

Comparative yields of the five metabolites isolated from P. tinctorum from LC-QQQ-MS analysis of the crude acetone extracts of the studied Parmotrema species ( $\mathrm{mol} / \mathrm{mg}$ dry weight \pm $\mathrm{SD})$

\begin{tabular}{cccccc}
\hline Lichen & $\begin{array}{c}\text { Orsellinic } \\
\text { Acid }\end{array}$ & $\begin{array}{c}\text { Lecanoric } \\
\text { Acid }\end{array}$ & $\begin{array}{c}\text { methyl } \beta- \\
\text { orsellinate }\end{array}$ & Norlobaridone & Atranorin \\
\hline PT & $0.19 \pm 0.01$ & $0.71 \pm 0.08$ & $0.006 \pm 0.0005$ & $0.02 \pm 0.0001$ & $0.42 \pm 0.005$ \\
PA & $0.01 \pm 0.0005$ & $0.35 \pm 0.01$ & $0.015 \pm 0.0005$ & - & $0.01 \pm 0.0004$ \\
PP & - & - & $0.014 \pm 0.0003$ & - & $0.051 \pm 0.001$ \\
PG & - & - & $0.04 \pm 0.0002$ & - & $0.068 \pm 0.002$ \\
PS & - & $0.53 \pm 0.06$ & $0.003 \pm 0.0001$ & - & $0.011 \pm 0.0002$ \\
\hline
\end{tabular}

\section{Table 3}

ABTS \% scavenging and formation of AGEs inhibition by lichen extracts.

\begin{tabular}{cccc}
\hline Lichen & ABTS \% scavenging & *AGEs \% Inhibition \\
extracts & at $50 \mu \mathrm{g} / \mathrm{mL}$ & at $20 \mu \mathrm{g} / \mathrm{mL}$ \\
\cline { 3 - 4 } & concentration $\left(\mathrm{SC}_{50}\right.$ & V type & P type \\
& $\mu \mathrm{g} / \mathrm{mL})$ & & \\
PT & $99.3(2.64)$ & $56.3 \pm 1.7$ & $47.6 \pm 1.3$ \\
PA & $99.5(4.74)$ & $\mathrm{NA}$ & $88.6 \pm 2.9$ \\
PP & $94.41(1.35)$ & $8.0 \pm 1.3$ & $75.7 \pm 0.6$ \\
PG & $98.01(7.42)$ & $\mathrm{NA}$ & $42.3 \pm 1.0$ \\
PS & NA & $68.2 \pm 4.2$ & $85.3 \pm 5.5$ \\
Trolox & $99.6(0.96)$ & & \\
Amino & & $97.2 \pm 0.3$ & $83.3 \pm 0.4$ \\
guanidine & & & \\
\hline
\end{tabular}

*Values represent mean $\pm \mathrm{SD}, \mathrm{n}=4$ 